\title{
Effective versus Statutory Taxation: Measuring Effective Tax Administration in Transition Economies
}

\author{
By: Mark E. Schaffer and Gerard Turley
}

Working Paper Number 347

November 2000 


\title{
Effective versus Statutory Taxation: Measuring Effective Tax Administration in Transition Economies
}

\author{
Mark E. Schaffer \\ M.E.Schaffer@hw.ac.uk \\ Centre for Economic Reform and Transformation \\ Department of Economics, School of Management \\ Heriot-Watt University \\ Edinburgh EH14 4AS, UK \\ Gerard Turley \\ G.Turley@hw.ac.uk \\ Department of Economics \\ National University of Ireland \\ Galway, Republic of Ireland
}

November 2000

\begin{abstract}
Wide differences between effective or realised average tax rates and tax yields that would result if statutory tax rates were strictly applied indicate tax compliance and collection problems. Due to the greater politicisation of tax systems in transition economies (TEs), we would expect the shortfalls in effective tax yields for TEs to be larger than a benchmark for the mature market economies where tax systems are well established, the administrative capacity is stronger and tax arrears are tolerated less frequently. The methodology involves calculating an effective/statutory $(\mathrm{E} / \mathrm{S})$ tax ratio. Initial results indicate that the leading TEs have $\mathrm{E} / \mathrm{S}$ ratios similar to the EU average. We find a positive correlation between progress in transition and effective tax administration, as measured by our E/S ratio. For slow reformers, the effectiveness of tax collection appears to vary with the extent of state control. Those TEs that have maintained the apparatus of the state have done well in tax collection compared to those countries where there is evidence of state decay. This raises a number of broad policy issues relating to the speed of transition, the interaction of politics and economic reforms, the capacity of the state to govern and the need for market institutions to develop.
\end{abstract}

Key words: statutory taxation, average tax rate, tax collection, effective administration, transition economies

Journal of Economic Literature, Classification Numbers: H2, H32, H87, P5. 5 tables, 32 references.

\footnotetext{
* The analysis in this paper builds on work conducted for the European Bank for Reconstruction and Development, to whom we are grateful for financial support. We are grateful also to Michael Alexeev, Alan Bevan, and the participants at the July 2000 Galway workshop on "Institutions in Transition Economies" for helpful comments earlier versions of this paper. All views expressed in this paper are, however, solely the responsibility of the authors.
} 


\section{Introduction}

This paper attempts to measure the effectiveness of tax administration in transition economies (TEs) and how it compares to a benchmark for the mature market economies. We measure the effectiveness of tax administration by comparing statutory tax rates with effective tax yields. This method of measuring the administrative capacity of tax systems has been alluded to in the taxation literature but not systematically pursued in cross-country comparisons. Alex Radian, in his inquiry into tax administration in poor countries, noted that effective tax rates are lower than legal tax rates (Radian, 1980). David Newbery raised the issue of differences between statutory and effective tax rates, again in the context of developing countries, when he stressed the importance of examining the effective tax system rather than the legally defined tax system (Newbery and Stern, 1987). In the same World Bank publication, Vito Tanzi suggested that the gap between the statutory tax system and the effective tax system might be large in developing countries (Newbery and Stern, 1987). Elsewhere, Burgess and Stern (1993) argued that the wedge between the statutory and effective tax systems can be reduced by improvements in administrative capabilities. In this paper, we take a methodology previously used for measuring fiscal or revenue capacity in federal states (ACIR 1962) and adapt it to enable inter-country comparisons of effective vs. statutory taxation. We then use actual fiscal and national accounts data from 25 TEs and, as a benchmark, the average for the 15 member countries of the European Union, to measure the effectiveness of tax administration.

Tax exemptions, deferrals, write-offs and arrears that firms receive or extract from the state are widespread, not only in transition economies but in market economies as well. In a broader sense, these tax concessions are often manifestations of a tax system that is politicised. One possible result of this bargaining and general politicisation of the tax system is a low level of tax compliance combined with a high incidence of tax avoidance. Measuring the extent of this financial aid using firm-level information is difficult and faces obvious data difficulties, e.g., these concessions may not be widely known or may not show up in the government's budget. By measuring the difference between effective and statutory taxation at the aggregate level, our

\footnotetext{
${ }^{1}$ This paper deals with tax avoidance as distinct from tax evasion. Tax avoidance is defined as the use of the tax system to minimise tax liabilities or obligations. It is a legal activity as distinct from the illegal (and acutely difficult to measure) activity of tax evasion. One way that enterprises can reduce their tax burden is by transferring their tax liabilities abroad. Transfer pricing is common in market economies where multinational corporations use their foreign subsidiaries that operate in low tax jurisdictions to reduce their overall tax burden. A well-known case is that of Rupert Murdoch's News Corporation, a company that
} 
methodology enables us to obtain aggregate measures of the degree of effectiveness of tax collection that can be compared across countries, for different taxes, and over time. In this paper we develop indicators that allow us to measure how broadly and strictly valued added tax, payroll tax and corporate income tax are implemented and complied with in TEs. We use the average of the EU-15 countries as an appropriate benchmark for comparison. Our focus is on comparisons for the most recent year available; comparisons over time will be pursued in future work.

\section{The Tax System in TEs}

The tax system that existed under the socialist command economy was different from a Westernstyle tax system. There was no corporate income tax system, in the usual sense of the term. State enterprises were subservient to the various ministries and any 'profits' made were expropriated by the state. Likewise, losses were made good by arbitrary pricing and subsidies. Often, tax rates were numerous and non-parametric, tax structures were complex and differentiated, and tax liabilities were discretionary and negotiable. The main sources of tax revenue were typically enterprise profit tax, turnover tax (with highly differentiated, product-specific rates) and payroll taxes; direct taxes on individuals were unimportant. Although taxation as a percentage of GDP was high in socialist countries, administrative costs were low and tax collection was straightforward as firms tended to be large and closely monitored. In the Soviet system, 'taxes' were collected from the enterprise, with the State Bank acting as the fiscal agent of the state. Once the socialist system collapsed, TEs, some lacking an explicit tax system (or culture), had to build a market-oriented, rule-based tax system (including a market-type tax administration) from scratch. The creation of a new tax system involved the introduction of a corporate income tax system. Not only did this involve changes in how enterprises were treated by the state in terms of taxation, but it was also introduced in conjunction with other policies, such as price liberalisation, demonopolisation and privatisation. A VAT system to replace the turnover tax was introduced in the early years of transition and was in place in most TEs by 1994. Tax on individuals accounted for a small proportion of the total tax take in socialist countries: the transition to a market economy meant that a personal income tax system as operates in market economies was also to be introduced.

made £1.4 billion in profits in Britain but reportedly paid no corporation tax there (The Economist, 29/1/00). 
In the context of TEs and taxation, we are interested in the hardening of budget constraints of firms. Hence, the firm is the unit of analysis in this paper. As for the different taxes paid by the firm, corporate income or profit tax, value-added tax and social security taxes are mostly linear, flat rate taxes. ${ }^{2}$ Neither sales taxes (because they are levied at one stage only) nor excise taxes (because they are product-specific) are considered in our study. We do, however, treat social security contributions as a payroll tax.

As mentioned above, we will concentrate on three taxes paid by the firm: corporate income tax (CIT), value-added tax (VAT) and social security tax (SST). Although VAT is essentially a tax charged on final purchasers, it is imposed at different stages of production at the firm level. For these three taxes, we estimate the difference between effective average tax rates and tax yields that would result if statutory tax rates were strictly applied. The methodology is explained below.

\section{Methodology}

Our methodology is based on one commonly used in measuring tax or fiscal capacity in federal states. The ACIR Representative Tax System (RTS) method was initially proposed in the early 1960s and has been modified on several occasions since then (see ACIR 1962; 1971; 1982). Essentially, by applying national average or representative tax rates to member-state tax bases, the RTS method shows the amount of revenue that could be collected by the individual member states of a federal country, i.e., their fiscal capacity. With some modifications, we apply this methodology to sovereign states (and transition countries, in particular) rather than to states within a federal system.

We begin with some definitions. Statutory tax rates are the rates that taxpayers are required to pay by law. Effective tax rates are the realised average tax rates. These are the same average tax rates as employed by Whalley (1975), Lucas (1990) and Mendoza et al. (1994).

\footnotetext{
${ }^{2}$ A linear tax is a tax whose marginal rate is constant.

${ }^{3}$ These are aggregate average tax rates as distinct from the effective marginal tax rates that are commonly used in studies of household income, income distribution and taxation. Aggregate tax rates are normally used in macroeconomic modeling and in the taxation, economic growth and supply-side economics debate. For the problems associated with measuring effective tax rates, see Fullerton (1984).
} 
Let $\mathrm{Y}$ be the gross tax base and $\mathrm{T}$ be actual tax payments; hence income net of tax is $\mathrm{Y}-\mathrm{T}$. We denote by $\mathrm{t}$ the statutory tax rate applied to gross income. The effective tax rate e, also defined on a gross basis, is calculated by dividing actual tax payments $\mathrm{T}$ by the appropriate gross tax base, or

$e \equiv \frac{T}{Y}$

Using the statutory and effective tax rates thus defined, we calculate two indicators that measure the effectiveness of tax administration. The first indicator is the ratio of effective tax to statutory tax. The effective/statutory $(E / S)$ ratio is defined as follows:

Effective/ statutory ratio $\equiv \frac{e}{t} \equiv \frac{T}{t Y}$

This indicator measures the extent of the wedge between the statutory tax rate and the realised average tax rate. A ratio close to 1 indicates that the effective tax rate is close to the statutory tax rate. A ratio below 1 indicates that the effective tax yield is falling short of what application of the statutory tax rate would yield. Differences across countries in the extent of this shortfall in revenue may be accounted for by tax breaks, tax arrears and tax avoidance measures.

As approximations of the gross tax base $\mathrm{Y}$, we use national accounts measures of income: for VAT, total national income (GDP); for SST, income from labour; and for CIT, income from capital. These are, of course, only rough approximations of the actual statutory tax bases. For example: even in market economies, large portions of the economy are exempt from VAT (e.g., public administration and education); corporate income tax applies only to corporations and the usual tax base is net of depreciation and interest; for all three taxes, entities must usually be over a certain size threshold before becoming liable for taxation. Furthermore, the national accounts statistics of transition countries are generally regarded as less reliable than those of developed market economies, including their statistics on the division of GDP into labour and capital income. National accounts measures of income do, however, have the important advantages of being both readily available and, in principle, readily comparable across countries. Moreover, 
our focus is not on levels of effective taxation in countries but on comparisons of levels across countries, and as noted the reasons for these deviations between income measures and statutory tax bases are found in all countries.

Our second indicator entirely avoids these possible problems with national accounts measures of income by simply not attempting to match tax payments to the appropriate tax base. The normalised tax yield (NTY) instead relates tax payments adjusted for cross-country differences in statutory rates to GDP, and is defined as follows:

Normalised tax yield $\equiv \frac{T}{G D P} \frac{b}{t}$

where $t$ is the statutory tax rate and $b$ is a benchmark rate. Put simply, the normalised tax yield tells us what the tax yield (for a particular tax) would be for a specific country if the statutory tax rate were the same for all countries.

In the definitions above, we have used the convention of a tax base that is gross of tax. In practice, statutory tax rates are sometimes defined relative to a tax base that is inclusive of tax and tax liabilities are paid out of gross income; and sometimes statutory rates are defined relative to a tax base that is net of tax. Corporate income tax (like personal income tax) is an example of the former; tax liability is calculated by applying the corporate tax rate to gross profit. VAT and SST are examples of the latter. Firms calculate their gross VAT liability by "adding on" VAT as a percentage of the pre-tax price, and SST is typically calculated as a percentage of wages and salaries paid. We use the former convention - the tax base is gross of tax - for our calculations for all three taxes considered. This requires adjustments to the statutory tax rate for both VAT and SST.

\footnotetext{
${ }^{4}$ Accounting for tax evasion will depend on whether the national accounts adjust for the hidden economy. If there is an evasion adjustment in the calculation of GDP, tax evasion is captured by our measure; how fully will depend on the accuracy of the adjustment.

${ }^{5}$ We are therefore using gross income only and adjusting statutory rates as necessary. The alternative approach would be to use statutory rates in conjunction with gross or net income, as appropriate. This approach, however, encounters data availability problems with net income. As noted above, we use national accounts measures of gross income that are only approximations of the actual tax base. Calculating net income from these approximations and the actual tax yield introduces further measurement error into the tax base approximations. By contrast, our tax rate adjustment in equation (5) is an identity and introduces no such measurement error.
} 
Denote by $\mathrm{t}^{\mathrm{N}}$ the tax rate applied to net income $\mathrm{Y}(1-\mathrm{t})$ that would yield the identical tax revenue as the tax rate $t$ applied to gross income $\mathrm{Y}$. We then have, by definition,

$$
t Y \equiv t^{N}[Y(1-t)]
$$

Rearranging equation (4) yields

$$
t \equiv \frac{t^{N}}{1+t^{N}}
$$

Equation (5) is used to convert a tax rate defined by statute as applying to net income into the equivalent tax rate on gross income.

We illustrate this adjustment by reporting the benchmark rates used to calculate our normalised tax yield indicator. We denote by $b^{\mathrm{N}}$ the benchmark net of tax rate equivalent to the gross rate $\mathrm{b}$. We take as our benchmark rates the approximate (rounded to the nearest five or ten per cent) average statutory tax rates in use in the 15 member states of the European Union: $b^{\mathrm{N}}=20 \%$ for VAT, $b^{\mathrm{N}}=40 \%$ for SST, and $b=35 \%$ for CIT. The following table reports the equivalent gross and net rates for these benchmarks; the figures in bold are the statutory rates as legally defined by statute.

\section{Table 1: Benchmark Tax Rates, Gross and Net Equivalents} Rates defined by statute in bold

\begin{tabular}{|l|l|l|}
\hline & $\mathrm{b}$ & $\mathrm{b}^{\mathrm{N}}$ \\
\hline VAT & $16.7 \%$ & $\mathbf{2 0 \%}$ \\
\hline SST & $28.6 \%$ & $\mathbf{4 0 \%}$ \\
\hline CIT & $\mathbf{3 5 \%}$ & $53.8 \%$ \\
\hline
\end{tabular}

\section{Data Coverage and Sources}

Our primary interest is in examining the administrative capacity of tax systems in TEs and how it compares to levels in well-established market economies. We use the mean of the EU-15 countries as a benchmark, taking 1996 as the benchmark year. 
There are 25 ex-socialist countries in our study; the TEs that are not included are those where tax data are difficult to obtain (Mongolia, Vietnam), where the tax system is highly complicated (China) or where war has occurred (Serbia-Montenegro, Bosnia-Herzegovina). Ten of our 25 countries are CEE countries (Albania, Bulgaria, Croatia, Czech Republic, FYR Macedonia, Hungary, Poland, Romania, Slovak Republic and Slovenia) for which we use data primarily for the period 1991 - 1997. The remaining 15 are all FSU countries (Armenia, Azerbaijan, Belarus, Estonia, Georgia, Kazakhstan, Kyrgyzstan, Latvia, Lithuania, Moldova, Russia, Tajikistan, Turkmenistan, Ukraine and Uzbekistan) for which the relevant period is $1992-1997$ [ All these countries have a corporate income tax system, of sorts. All 25 countries with the exception of Croatia, FYR Macedonia and Slovenia had a VAT system in place by 1996. All TEs in our study have a social security tax system mostly financed by payroll taxes, with contributions being made by employers and/or employees. For all countries in our study, tax coverage is for general government, comprising of central and state, regional or provincial units of government and local government.

An exercise in calculating statutory versus effective taxation depends on data pertaining to tax rates, tax takes and tax bases. As for statutory taxation, the basic tax rates are taken primarily from international tax handbooks. In particular, we used the IBFD's European Tax Handbook, Coopers \& Lybrand's International Tax Summaries and Ernst \& Young's Worldwide Tax Guides. We also used various EBRD Transition Reports. Tax payments were obtained from the governments' fiscal accounts where taxes are reported on a cash basis, i.e., counting actual receipts rather than accrued liabilities. Where possible, tax payments data are from the IMF's Government Finance Statistics Yearbook (GFSY) or the CIS Statistical Yearbook. Other publications used include the OECD's Revenue Statistics, the IMF's Staff Country Reports and statistical yearbooks for various countries.

As already mentioned, the tax bases for the three types of taxes are taken from the national accounts. For VAT, we use GDP as a proxy for the VAT base. Although in all VAT systems there are some goods and services that are exempt from VAT, the most important of these exemptions are quite standard (e.g., public administration, education) and hence GDP is a reasonable proxy. For CIT, we use gross operating surplus as a proxy for the tax base on corporate capital income. Operating surplus corresponds to value added after deducting the compensation of employees and net taxes on production; it is the balancing item in the national

\footnotetext{
${ }^{6}$ The USSR was disbanded in December 1991 and was replaced by fifteen independent republics.
} 
accounts. Due to the difficulties in acquiring reliable estimates for the operating surplus of corporations for 25 countries, we instead use the operating surplus of the economy 7 For SST, we use compensation of employees as a proxy for the tax base. Compensation of employees is the sum of gross wages and salaries plus employers' social contributions.

Although imperfect, these are reasonably good approximations given the omissions in the national accounts, the dubious nature of some transition countries' data and the cross-country nature of the exercise. The main publications used for national accounts data are the IMF's International Financial Statistics Yearbook, the OECD's National Accounts Main Aggregates, the CIS Statistical Yearbook and statistical yearbooks for various countries.

The data sources used for all 25 countries are listed in Table 5, in the Appendix.

The statutory tax rates and the actual tax/GDP ratios for each of the 3 taxes, for our 25 countries are reported in Table 2.

\footnotetext{
${ }^{7}$ Likewise, we use gross rather than net operating surplus because the treatment of depreciation varies from one jurisdiction to another. Aside from depreciation provisions, corporate tax systems differ from country to country, in respect of treatment of interest payments, stock appreciation provisions and integration with the personal income tax system. Accordingly, computations arising from cross-country comparisons of corporate tax systems should be treated with caution. This is particularly true when the cross-country comparisons include the likes of Russia whose accounting rules are different to international standards.
} 
Table 2: $\quad$ Statutory Tax Rates and Tax/GDP Ratios for 25 TEs, 1997

\begin{tabular}{|l|c|c|c|c|c|c|}
\hline Country & \multicolumn{2}{|c|}{ VAT } & \multicolumn{2}{c|}{ SST } & \multicolumn{2}{c|}{ CIT } \\
\hline & $\begin{array}{l}\text { Statutory } \\
\text { tax rate }\end{array}$ & VAT/GDP & $\begin{array}{l}\text { Statutory } \\
\text { tax rate }\end{array}$ & SST/GDP & $\begin{array}{l}\text { Statutory } \\
\text { tax rate }\end{array}$ & CIT/GDP \\
\hline CEE Countries & & & & & & \\
\hline Albania & 12.5 & 4.6 & 42.5 & 3.9 & 30 & 0.7 \\
\hline Bulgaria & 22 & 6.2 & 44 & 6.9 & 36 & 6.4 \\
\hline Croatia & -- & -- & 43.4 & 14.4 & 35 & 2.0 \\
\hline Czech Republic & 22 & 7.1 & 47.5 & 15.2 & 39 & 3.4 \\
\hline FYR Macedonia & -- & -- & 30.1 & 12.3 & 15 & 0.7 \\
\hline Hungary & 25 & 7.9 & 57 & 13.1 & 18 & 1.9 \\
\hline Poland & 22 & 8.3 & 48.2 & 11.0 & 38 & 3.1 \\
\hline Romania & 18 & 4.7 & 34 & 7.1 & 38 & 4.3 \\
\hline Slovak Republic & 23 & 8.4 & 50 & 14.4 & 40 & 3.7 \\
\hline Slovenia & -- & -- & 38 & 13.8 & 25 & 1.2 \\
\hline & & & & & & \\
\hline FSU Countries & & & & & & \\
\hline Armenia & 20 & 3.3 & 38 & 2.9 & 30 & 2.5 \\
\hline Azerbaijan & 20 & 3.8 & 39 & 2.5 & 32 & 2.8 \\
\hline Belarus & 20 & 9.4 & 37 & 10.1 & 30 & 4.7 \\
\hline Estonia & 18 & 10.4 & 33 & 10.7 & 26 & 1.9 \\
\hline Georgia & 20 & 3.2 & 34 & 2.2 & 20 & 0.6 \\
\hline Kazakhstan & 20 & 3.5 & 32 & 6.2 & 30 & 2.4 \\
\hline Kyrgyzstan & 20 & 5.6 & 37 & 5.9 & 30 & 1.1 \\
\hline Latvia & 18 & 8.8 & 37 & 10.5 & 25 & 2.4 \\
\hline Lithuania & 18 & 8.7 & 31 & 7.0 & 29 & 1.6 \\
\hline Moldova & 20 & 9.4 & 40 & 7.2 & 32 & 2.4 \\
\hline Russia & 20 & 7.2 & 39.5 & 9.9 & 35 & 4.2 \\
\hline Tajikistan & 20 & 1.5 & 38 & 1.6 & 40 & 1.2 \\
\hline Turkmenistan & 20 & 7.2 & 31 & 4.5 & 25 & 5.2 \\
\hline Ukraine & 20 & 8.1 & 40 & 11.1 & 30 & 6.1 \\
\hline Uzbekistan & 17 & 6.1 & 43 & 6.7 & 37 & 7.9 \\
\hline Sorces: & & & & & \\
\hline
\end{tabular}

Sources: IBFD, 1998; IMF 1999.

Notes: (1) The figures for Armenia and Uzbekistan are for 1996. $--=$ not applicable.

As we can see from Table 2, many of the 25 transition countries in our study have the same statutory tax rates. This is particularly true for value-added tax where 11 of the FSU countries have a VAT rate of 20 per cent. Yet, the actual tax/GDP ratios across countries differ quite substantially. Assuming tax bases are not too dissimilar across countries, one interpretation of differences in tax ratios is the quality of tax administration across countries. The methodology outlined in section three allows us to investigate this further. 


\section{Results and Analysis}

Table 3 is a cross-country comparison showing the two indicators for the three different taxes for the 25 transition countries. We report estimates for the TEs for 1997 as the 1998 data for some FSU countries is distorted by the August 1998 Russian crisis. The benchmark is the 1996 average of the EU-15 countries. Our estimates are highly approximate and precise values should be treated accordingly. Nevertheless, they do provide a measure of effective tax administration and, in the case of some TEs, point to poor tax collection and weak tax administration.

\footnotetext{
${ }^{8}$ Treisman (1999) uses a 'tax accounting' method to measure the effectiveness of tax collection, in Russia. In his paper, the unexplained parts of the fall in tax revenues are attributed to the poor quality of tax administration, i.e. ineffective tax collection.
} 
Table 3: Statutory and Effective Taxation, 1997

$\mathrm{E} / \mathrm{S}=$ effective/statutory ratio; NTY $=$ normalised tax yield

\begin{tabular}{|c|c|c|c|c|c|c|c|}
\hline \multirow[t]{2}{*}{ Country } & \multicolumn{2}{|c|}{ VAT } & \multicolumn{2}{|c|}{ SST } & \multicolumn{2}{|c|}{ CIT } & \multirow{2}{*}{$\begin{array}{c}\text { EBRD } \\
\text { Transition } \\
\text { Indicator }\end{array}$} \\
\hline & $\mathbf{E} / \mathbf{S}$ & NTY & $\mathbf{E} / \mathbf{S}$ & NTY & $\mathbf{E} / \mathbf{S}$ & NTY & \\
\hline \multicolumn{8}{|l|}{ CEE Countries } \\
\hline Albania & 0.42 & 7.0 & n.a. & 3.7 & n.a. & 0.8 & 2.58 \\
\hline Bulgaria & 0.34 & 5.7 & 0.61 & 6.5 & 0.31 & 6.3 & 2.75 \\
\hline Croatia & -- & -- & n.a. & 13.6 & n.a. & 2.0 & 3.00 \\
\hline Czech Republic & 0.40 & 6.6 & 0.94 & 13.5 & 0.23 & 3.0 & 3.46 \\
\hline FYR Macedonia & -- & -- & n.a. & 15.2 & n.a. & 1.6 & 2.63 \\
\hline Hungary & 0.40 & 6.6 & 0.80 & 10.3 & 0.26 & 3.7 & 3.67 \\
\hline Poland & 0.46 & 7.7 & 0.76 & 9.7 & 0.20 & 2.9 & 3.42 \\
\hline Romania & 0.31 & 5.1 & 0.83 & 8.0 & 0.21 & 4.0 & 2.67 \\
\hline Slovak Republic & 0.45 & 7.5 & 0.93 & 12.3 & 0.22 & 3.3 & 3.25 \\
\hline Slovenia & -- & -- & 0.94 & 14.3 & 0.15 & 1.6 & 3.21 \\
\hline \multicolumn{8}{|l|}{ FSU Countries } \\
\hline Armenia $^{1}$ & 0.20 & 3.3 & 0.27 & 3.0 & 0.16 & 3.0 & 2.38 \\
\hline Azerbaijan & 0.23 & 3.8 & 0.46 & 2.6 & 0.12 & 3.1 & 2.04 \\
\hline Belarus & 0.57 & 9.4 & 0.87 & 10.7 & 0.39 & 5.4 & 1.63 \\
\hline Estonia & 0.68 & 11.4 & 0.83 & 12.3 & 0.22 & 2.6 & 3.42 \\
\hline Georgia & 0.19 & 3.2 & 0.38 & 2.5 & 0.04 & 1.1 & 2.71 \\
\hline Kazakhstan & 0.21 & 3.5 & 0.68 & 7.3 & 0.15 & 2.8 & 2.71 \\
\hline Kyrgyzstan & 0.34 & 5.6 & 0.68 & 6.2 & 0.06 & 1.3 & 2.83 \\
\hline Latvia & 0.58 & 9.6 & 0.76 & 11.1 & 0.23 & 3.4 & 3.08 \\
\hline Lithuania & 0.57 & 9.6 & 0.71 & 8.4 & 0.13 & 2.0 & 3.04 \\
\hline Moldova & 0.56 & 9.4 & 0.60 & 7.2 & 0.18 & 2.6 & 2.63 \\
\hline Russia & 0.43 & 7.3 & 0.71 & 10.0 & 0.33 & 4.2 & 3.00 \\
\hline Tajikistan & 0.09 & 1.5 & 0.31 & 1.6 & 0.04 & 1.0 & 1.58 \\
\hline Turkmenistan & 0.43 & 7.2 & n.a. & 5.5 & n.a. & 7.3 & 1.46 \\
\hline Ukraine & 0.49 & 8.2 & 0.80 & 11.1 & 0.63 & 7.1 & 2.46 \\
\hline Uzbekistan $^{1}$ & 0.42 & 7.0 & 0.61 & 6.4 & 0.47 & 7.5 & 2.38 \\
\hline EU-15 Mean & 0.45 & 7.4 & 0.88 & 12.5 & 0.24 & 3.0 & \\
\hline
\end{tabular}

Notes: (1) The estimates for Armenia and Uzbekistan are for 1996.

$--=$ not applicable. n.a. $=$ not available.

EBRD Transition Indicator: average indicator for 1997

As we can see from the table, the (unweighted) means of the E/S ratios in the EU-15 for VAT, SST and CIT are $0.45,0.88$ and 0.24 respectively. When we normalise the EU-15 VAT, SST and CIT yields at our benchmark rates of $20 \%(\mathrm{~b}=16.7 \%), 40 \%(\mathrm{~b}=28.6 \%)$ and $35 \%$ respectively, we get normalised tax yields of 7.4, 12.5 and 3.0 percent of GDP respectively. How do the rates for TEs compare with these levels for the EU? 
The results indicate that the 25 transition countries on average are not as effective in tax collection or enforcement compared to the average for EU countries. The (unweighted) means of the E/S ratio for the TEs for VAT, SST and CIT are 0.40, 0.69 and 0.23 respectively. Moreover, the variations from the mean are large for the TEs, compared to the EU countries. For the EU-15 countries, the standard deviations of the E/S ratio for the three tax categories are 0.06, 0.18 and 0.12 respectively. This compares to $0.15,0.20$ and 0.14 respectively for the TEs.

For many transition countries, revenue erosion has become a serious obstacle in their attempts to embrace effective fiscal policy. 2 Pre-transition, many ex-socialist economies had high government revenue shares of GDP. With most of economic activity taking place in the state sector, tax collection was a straightforward task. In contrast, for a market economy, the private sector dominates and confrontation between taxpayers and tax collectors is not uncommon. Thus, in the transition from a centrally planned to a market economy, a fall in revenue was not unexpected. Yet, for some transition economies, the fall in revenue has been excessive, with tax/GDP ratios currently at levels below what is considered normal in many market economies. Of course, for many TEs with income per capita levels below $\$ 1,000$ per annum, tax capacity is low (see Tait, Gratz, and Eichengreen, 1979). Our research indicates that, in addition to having a low tax capacity, TEs have relatively low tax effectiveness rates.

We now turn our attention to factors related to effective tax administration in transition countries. We begin by investigating the relationship between the effectiveness of tax collection and progress in transition. A priori, we might expect to find a positive relationship between progress in transition and effective tax administration.

We take as our measure of progress in transition the average of the EBRD transition indicators for 1997: 10 these are reported in Table 3 for all 25 TEs in our study. We present the relationship between progress in transition and the effectiveness of tax administration by means of a scatterplot in which the average EBRD transition indicator is plotted on the X-axis and the E/S

\footnotetext{
${ }^{9}$ The primary objective of taxation is to raise revenues, as efficiently and equitably as possible, in order to finance government spending. It was the great French financier Jean-Baptiste Colbert (1619-83) who once said, "The art of taxation consists in so plucking the goose as to obtain the largest possible amount of feathers with the smallest possible amount of hissing." In many of the FSU countries, the government's revenue problem is further exasperated by the realisation that a portion of revenue is in non-cash form.

${ }^{10}$ The EBRD transition indicators are a set of numerical indicators across a range of dimensions, under the headings - markets and trade, enterprises, and financial institutions. The purpose is to measure the progress of economic reforms. A more detailed explanation can be found in any of the EBRD Transition Reports.
} 
ratio is plotted on the Y-axis. This exercise is carried out separately for the three categories of taxes covered in our study ${ }^{11}$ The horizontal line in each of the scatterplots is the relevant EU mean, plotted to provide a benchmark for comparison. All three scatterplots are depicted in Figure 1. Our second indicator, the normalised tax yield (NTY) is plotted against the average EBRD transition indicator in Figure 2. As the E/S ratio and the NTY measure are highly correlated, the scatterplots in Figures 1 and 2 are similar.

The relationship between progress in transition and effectiveness of tax administration comes out quite clearly in two of the three taxes we are examining, namely VAT and SST. The largest difference is between the so-called leading reformers (Poland, Hungary, Slovenia, Czech and Slovak Republics, the Baltic States) and the laggard reformers (the Balkans and most of the CIS countries), but there are other differences of interest between the TEs. One interesting comparison is between the Ukraine and Russia. Although Russia has made more progress in transition (as judged by the EBRD transition indicators) than the Ukraine, it fares worse in terms of tax collection (as measured by our E/S ratio). Russia's poor relative performance as regards tax collection may have something to do with the nature of its federal tax system. ${ }^{12}$ In particular, perverse incentives arising from divided property rights between different levels of government exasperate the tax collection problems in Russia. It is not uncommon for enterprises and regional governments to collude against the federal government and the tax collection agency, the STS (State Tax Service). Likewise, any improvements in tax collection at subnational levels are likely to be penalised or "taxed away" by reductions in transfers (see Shleifer and Treisman, 2000). 3

We examine the three categories of taxes separately. In the discussion that follows, we only refer to one set of scatterplots, namely Figure 1.

\section{- Value-Added Tax}

There is a strong positive correlation between progress in transition and the effectiveness of VAT collection. All the leading reformers that have a VAT system have E/S ratios that are close to the EU benchmark of 0.45 . These advanced reformers are all clustered in the top right-hand corner

\footnotetext{
${ }^{11}$ As we can see from Table 3, the results for CIT are different to those for either VAT or SST. This observation applies to the two groups of countries in our study, namely EU countries and transition countries. Accordingly, in any analysis of our calculations, we treat the three categories of taxes separately.

${ }^{12}$ Recently described as a 'country that has moderate statutory tax rates but a corrupt system of tax administration.' (see Friedman et al., 1999).

${ }^{13}$ According to various sources, tax collection (and, in particular, federal tax) improved in Russia in 1999.
} 
of Figure 1a. In contrast, the majority of the laggard reformers are clustered in the bottom lefthand quadrant: the slow reformers have E/S ratios below the EU benchmark. The interesting feature is captured in the top left-hand quadrant where a small number of slow reformers (Moldova, Belarus, Turkmenistan and Ukraine) have high E/S ratios. Slow reformers with relatively high E/S ratios and normalised VAT yields may be accounted for by the observation that these TEs have maintained a functioning state, a feature that may have prevented the revenue erosion that is prevalent in most of the slow reforming TEs. 14

\section{- Social Security Tax}

As in the case of VAT, there appears to be a positive correlation between progress in transition and the effectiveness of SST collection. All the leading reformers occupy the top right-hand quadrant of Figure 1b. This group of TEs has E/S ratios similar to the EU benchmark of 0.88 . This is in sharp contrast to the bulk of the slow reformers that have E/S ratios and normalised tax yields below the EU benchmark. Among this group, the lowest E/S ratios are concentrated in TEs that have suffered internal conflicts (Armenia, Azerbaijan and Tajikistan) or that have witnessed a collapse of the state (Georgia, for example). Again, we see that there are a small number of so-called slow reformers that have managed to maintain tax discipline, in this case with respect to payroll taxes. Belarus and the Ukraine both have $\mathrm{E} / \mathrm{S}$ ratios close to the $\mathrm{EU}$ benchmark. As with VAT collection, strong presidential leadership (Lukashenka and Kuchma, respectively) combined with functioning state institutions, albeit in need of reform, may explain these high $\mathrm{E} / \mathrm{S}$ ratios and normalised tax yields.

\section{- Corporate Income Tax}

The mean of the E/S ratio in the EU-15 for corporate income tax is 0.24 . The normalised tax yield is three per cent of GDP. Again, we see from Figure 1c that the leading TEs are all tightly clustered around the EU benchmark. This contrasts sharply with the laggard reformers, some with E/S ratios above the EU level. One possible explanation for why some of the slow reformers

\footnotetext{
${ }^{14}$ The ability of some slow reforming TEs to collect tax (Ukraine and Belarus, in particular) has been alluded to in the transition literature, in Murrell (1996), EBRD (1994, 1999) and elsewhere. Johnson, Kaufmann and Shleifer (1997) argue that it is the repressive nature of states (Belarus, possibly Uzbekistan and Turkmenistan) and their willingness to suppress the unofficial economy that explains high collection rates. The case of Moldova is less clear. For example, it is true that VAT collection in Moldova has improved, due to the recent elimination of many exemptions. Nonetheless, its total tax/GDP ratio, at close to $30 \%$ in 1997 , seems very high for a country with a GDP per capita of less than $\$ 600$. One possible explanation is that the GDP figure may be an underestimate, failing to adequately account for the unofficial economy.
} 
have high normalised CIT yields is the upward inflation bias in profits arising from historical cost accounting. High inflation rates prevalent in TEs would generate large profits and high tax yields. This may explain why the leading TEs, in general, experience a fall in the E/S ratio for CIT during the transition period. The average E/S ratio in 1991, at the beginning of transition, for Hungary, Poland and Czechoslovakia was 0.42. By 1997 the average E/S ratio for these (now four) advanced reformers had fallen to 0.23 .

To summarise, leading reformers (advanced CEE countries and the Baltic States) and countries that have maintained a functioning state (Belarus, Ukraine and Uzbekistan) have higher levels of tax compliance and collection than either slow reformers (Romania, Bulgaria), 15 countries with decaying or corrupt states (Russia, Georgia) or countries that have suffered internal conflicts (Armenia, Azerbaijan, Tajikistan). A somewhat similar result emerged from the EBRD/WB Business Environment and Enterprise Performance Survey (BEEPS) section on progress in economic reform, quality of governance and state intervention (see text below). Whereas countries that have adopted partial reforms score badly in terms of the quality of governance, it is the most advanced and the least advanced countries that score well in terms of governance. Likewise, the survey results indicate that “...progress in transition is not necessarily synonymous with a reduction in state intervention in enterprises" (EBRD, 1999, p.122). Again, high levels of state intervention are evident in many of the leading transition countries and in the least advanced transition countries. These results raise serious issues, including the need to rethink, in the context of the transition experience and often in a political and institutional vacuum, the state's capacity to govern and the need for market institutions to develop.

The EBRD's transition indicators summarise overall "progress in transition". We now briefly explore one possible specific contributor to the ineffectiveness of tax administration, namely corruption and bribery. It is not uncommon for enterprises in TEs (and in market economies, although presumably less so) to pay bribes to government officials in return for various services or favours. As these payments are direct private benefits to public officials, they do not turn up in the government fiscal accounts. Yet, in all other respects, they can be viewed as unofficial taxes that add to the tax burden of enterprises. Is it possible that TEs that report low 'official' tax revenue shares as a percentage of GDP have high 'unofficial' taxes, in the form of bribes?

\footnotetext{
15 After the 1996/97 financial crisis in Bulgaria, the authorities introduced various reform measures, including changes to the tax administration system. These and other tax reform measures contributed to an improvement in tax collection in 1998, reflected in higher E/S ratios for both VAT and SST.
} 
In Table 4 we reproduce a measure of the extent to which firms pay bribes to government officials. The measure was constructed from the BEEPS, conducted by the EBRD and the World Bank in over 3,000 firms in 20 countries and reported in EBRD (1999). To estimate a measure of bribes, firms were asked what percentage of annual revenues were made by 'firms like yours' in 'unofficial payments' to public officials. In the countries surveyed, the average bribe tax ranges from a low of 2.1 per cent of annual revenues in Croatia to a high of 8.1 per cent in Georgia. For comparison, Transparency International's Corruption Perceptions Index (CPI), the most recognised measure of corruption, is also reported. ${ }^{16}$

Table 4: Bribe tax and Corruption for TEs

\begin{tabular}{|l|c|c|l|c|c|}
\hline Country & $\begin{array}{c}\text { Ave. Bribe } \\
\text { Tax }\end{array}$ & CPI & Country & $\begin{array}{c}\text { Ave. Bribe } \\
\text { Tax }\end{array}$ & CPI \\
\hline CEE Countries & & & FSU Countries & & 6.8 \\
\hline Albania & na & 7.7 & Armenia & 6.6 & 8.3 \\
\hline Bulgaria & 3.5 & 6.7 & Azerbaijan & 3.1 & 6.6 \\
\hline Croatia & 2.1 & 7.3 & Belarus & 2.8 & 4.3 \\
\hline Czech Republic & 4.5 & 5.4 & Estonia & 8.1 & 7.7 \\
\hline FYR Macedonia & na & 6.7 & Georgia & 4.7 & 7.7 \\
\hline Hungary & 3.5 & 4.8 & Kazakhstan & 5.5 & 7.8 \\
\hline Poland & 2.5 & 5.8 & Kyrgyzstan & na & 6.6 \\
\hline Romania & 4.0 & 6.7 & Latvia & 4.2 & 6.2 \\
\hline Slovak Republic & 3.7 & 6.3 & Lithuania & 6.1 & 7.4 \\
\hline Slovenia & 3.4 & 4.0 & Moldova & 4.1 & 7.6 \\
\hline & & Russia & na & na \\
\hline & & & Tajikistan & na & na \\
\hline & & & Ukraine & 6.5 & 7.4 \\
\hline & & Uzbekistan & 5.7 & 8.2 \\
\hline
\end{tabular}

Sources: EBRD Transition Report 1999; Transparency International's website http://www.transparency.de/

Figures $3 \mathrm{a}$ and $3 \mathrm{~b}$ plot our E/S ratio measure for VAT and SST against the average bribe tax as a percentage of annual firm revenues, for 18 and 19 transition countries respectively 17 Countries that have a high measure of effective tax administration (Estonia, Poland and Belarus, for example) also have a relatively low average tax bribe. In contrast, countries with ineffective tax

\footnotetext{
${ }^{16}$ The organisation Transparency International ranks countries, on the basis of surveys, in terms of the degree to which corruption is perceived to exist among public officials and politicians. The CPI score ranges from 0 (highly corrupt) to 10 (virtually corrupt free). To allow for comparisons with the BEEPS bribery tax, we have adjusted the CPI scores, e.g. Bulgaria's CPI score of 3.3 is adjusted to 6.7. The CPI scores recorded in Table 4 are for 1999; scores for previous years are unavailable for many of the TEs.

${ }^{17}$ From the 20 countries in the EBRD/WB survey, we exclude Croatia and Slovenia from Figure $3 \mathrm{a}$ as neither country had a VAT system in place in 1997. Figure $3 \mathrm{~b}$ does not include Croatia as there is no E/S ratio available.
} 
administration (Armenia, Azerbaijan and Georgia, for example) have a relatively high average tax bribe. The correlation coefficients are -0.54 and -0.74 respectively. As we did before, we plot the normalised tax yield (NTY) in Figure 4. Again, as we expect, the scatterplots in Figures 3 and 4 are similar.

If we use Transparency International's CPI as the measure of corruption, we get similar results. Although interesting, more evidence needs to be gathered before any strong conclusions can be drawn.

\section{Conclusions and Further Research}

In this paper we adopted an existing methodology to measure the effectiveness of tax administration. Comparing effective with statutory taxation allows us to get a handle on the administrative capacity of tax systems. The results indicate that, on average, the 25 TEs are not as effective in tax collection as compared to the average of the EU countries. A more surprising result is the differences between TEs: in particular, the ability of some slow reformers to maintain high tax collection rates.

As for policy implications, tax administration reforms have lagged behind general tax reforms since transition began, often because administrative reforms (and consequently the benefits) take time. Market-oriented fiscal institutions (tax administration, treasury) do not develop overnight. Administrative reforms involve changes in incentives and in the behaviour of taxpayers and public officials. In general, TEs with tax collection problems need to widen the tax base by subjecting previously exempt income to taxation, reduce exemptions and allowances and, where possible, implement lower (to discourage tax avoidance and evasion) and single (to avoid the rent-seeking activities of producers) tax rates. Ending the tradition of bargaining and negotiating between the authorities and the taxpayer might prove more difficult given the political constraints in TEs. For federal systems (Russia, for example), intergovernmental fiscal relations need to be rule-based and transparent. Specific tax administration measures for TEs might include strengthening the tax administration (assessment, collection, enforcement) agencies in terms of organisation and personnel (as well as the legal and accounting professions), codification of the various tax laws, greater efforts at improving the data on taxpayers, simplifying the registering, reporting and filing requirements, greater penalties (monetary and otherwise) for non-compliance 
and/or positive encouragement for compliance and educating taxpayers about their obligations. In the implementation of these reforms, it is important that the constraints (and the traditional values and practices) of TEs are recognised. 18

As for future work, we would like to extend our data coverage to a larger set of countries. In particular, we would like to include non-EU OECD countries and, where possible, developing countries. Inclusion of non-EU OECD countries would provide us with an alternate and possibly more suitable benchmark to the EU-15. The more interesting possibility would be to apply our methodology to tax data for a range of developing countries in Latin America, Asia and Africa and for the Newly Industrialised Countries of South East Asia. This would allow us to compare ex-socialist transition countries with countries that closely resemble TEs either in terms of initial conditions or in terms of a 'transition' experience. For example, a more suitable comparison for the fast growing countries like Poland, Estonia and Hungary might be the Tiger countries of South East Asia. Likewise, the FSU countries of Central Asia and the Caucasus states more resemble, in terms of GDP per capita and sectoral composition, developing countries than EU countries. One implication of this would be a need to extend the tax classifications to include foreign trade taxes. Although revenue from duties on international trade is tiny for EU countries, it is a major source of revenue for developing countries and for some transition countries. By extending the coverage to developing countries, it would also allow us to make more meaningful policy prescriptions as regards tax reform for transition countries. This is the next step in our research. Alternately and in the context of EU enlargement, tax harmonisation and fiscal convergence, our effective tax rates can be used to examine the overall tax burden and the distribution of the tax burden across different tax bases in EU countries and in the transition accession countries. We will pursue this work at a later stage.

In this paper, we briefly examined some factors that might impinge on tax administration and collection in transition countries. In particular, we explored the significance of two factors, namely progress in transition and corruption. We would like to extend this line of research. Other possible explanatory factors may include the shadow economy and tax evasion, the initial conditions, political constraints and the distribution of power, GDP per capita and levels of

\footnotetext{
${ }^{18}$ Many of the TEs are poor with very low incomes per capita. In 1997, the Caucasus states of Armenia, Azerbaijan and Georgia had an (unweighted) average GDP per capita of US\$640 approximately. The five Central Asian states (Kazakhstan, Kyrgyzstan, Tajikistan, Turkmenistan and Uzbekistan) had an average GDP per capita of approximately US\$615 (EBRD, Transition Report 1999).
} 
development. Some of these factors are not unique to TEs, applying to developing and developed countries alike.

With respect to fiscal and tax reform, the first decade of transition has focused primarily on tax design. If further revenue erosion is to be avoided, the next decade must concentrate on administrative reform. In the Transition Report 1994, the EBRD called for a strengthening of tax administration, an issue that "lies at the core of fiscal reform. 19 For many TEs, this policy recommendation is as relevant today as it was in the early years of transition.

${ }^{19}$ EBRD, 1994, p.88. 


\section{REFERENCES}

Advisory Commission on Intergovernmental Relations (ACIR), Measures of State and Local Fiscal Capacity and Tax Effort, M-16, Washington D.C., 1962.

Burgess, Robin and Nicholas Stern, "Taxation and Development," Journal of Economic Literature, 31, 762 - 830, 1993.

Ebrill, Liam and Oleh Havrylyshyn, eds., "Tax Reform in the Baltics, Russia, and other Countries of the Former Soviet Union," IMF Occasional Paper No. 182, Washington D.C.: International Monetary Fund, 1999.

Clyde Reeves, H. ed., Measuring Fiscal Capacity. Oelgeschlager, Gunn \& Hain in association with the Lincoln Institute of Land Policy, 1986.

European Bank for Reconstruction and Development, Transition Report 1999: Ten Years of Transition. London: EBRD, 1999.

European Bank for Reconstruction and Development, Transition Report 1994. London: EBRD, 1994.

Friedman, Eric, Simon Johnson, Daniel Kaufmann and Pablo Zoido-Lobaton, "Dodging the Grabbing Hand: The Determinants of Unofficial Activity in 69 Countries." Paper presented at the Fifth Nobel Symposium in Economics: The Economics of Transition, Stockholm, September 10 $12,1999$.

Fullerton, Don, “Which Effective Tax Rates?,” National Tax Journal, 37, 23 - 41, 1984.

Holzman, Franklyn, D., Soviet Taxation: The Fiscal and Monetary Problems of a Planned Economy. Cambridge: Harvard University Press, 1962.

International Bureau of Fiscal Documentation, European Tax Handbook. Amsterdam: IBFD, 1998.

International Monetary Fund, Government Finance Statistics Yearbook 1999. Washington, D.C.: IMF, 1999.

International Monetary Fund, International Financial Statistics Yearbook 1999. Washington, D.C.: IMF, 1999

Interstate Statistical Committee of the Commonwealth of Independent States, Commonwealth of Independent States in 1998: Statistical Yearbook. Moscow: Statistical Committee of the CIS, 1999.

Johnson, Simon, Daniel Kaufmann and Andrei Shleifer, "The Unofficial Economy in Transition," Brookings Papers on Economic Activity, 2: 159 - 221, 1997. 
Lopez-Claros, Augusto and Sergei V. Alexashenko, "Fiscal Policy Issues during the Transition in Russia," IMF Occasional Paper No. 155, Washington D.C.: International Monetary Fund, 1998.

Lucas, Robert E., Jr., "Supply-Side Economics: An Analytical Review," Oxford Economic Papers, 42, 2: 293 - 316, 1990.

Mendoza, Enrique G., Assaf Razin and Linda L. Tesar, "Effective Tax Rates in Macroeconomics: Cross-Country Estimates of Tax Rates on Factor Incomes and Consumption,” Journal of Monetary Economics, 34, 3: 297 - 323, 1994.

Murrell, Peter, "How Far Has the Transition Progressed?," Journal of Economic Perspectives, 10, 2: 25 - 44, Spring 1996.

Newbery, David, ed., Tax and Benefit Reform in Central and Eastern Europe. London: Centre for Economic Policy Research, 1995.

Newbery, David, "Taxation and Development," in David Newbery and Nicholas Stern, eds., The Theory of Taxation for Developing Countries, Oxford University Press for the World Bank, Washington, D.C., 1987, 165 - 204.

Organisation for Economic Co-operation and Development, OECD National Accounts Main Aggregates 1960 - 1997. Paris: OECD, 1999.

Organisation for Economic Co-operation and Development, OECD Revenue Statistics 1965 1998. Paris: OECD, 1999.

Radian, Alex, Resource Mobilization in Poor Countries: Implementing Tax Policies. New Brunswick, NJ: Transaction Books, 1980.

Schaffer, Mark E. and Lorand Ambrus-Lakatos, eds., Fiscal Policy in Transition, Forum Report of the Economic Policy Initiative, no.3. London: Centre for Economic Policy Research; Warsaw and New York: Institute for EastWest Studies, 1997.

Shleifer, Andrei and Daniel Treisman, Without a Map: Political Tactics and Economic Reform in Russia. Cambridge, Massachusetts: MIT Press, 2000.

Slemrod, Joel, ed., Why People Pay Taxes: Tax Compliance and Enforcement. Ann Arbor: University of Michigan Press, 1992.

Surrey, Stanley, "Tax Administration in Underdeveloped Countries," in Richard Bird and Oliver Oldman, eds., Readings on Taxation in Underdeveloped Countries. Baltimore, Maryland: John Hopkins Press, 1964, 503 - 533.

Tait, Alan A., Wilfrid L. M. Gratz, and Barry J. Eichengreen, "International Comparisons of Taxation for Selected Developing Countries, 1972 - 1976," IMF Staff Papers, 26, 1: 123 - 56, 1979. 
Tanzi, Vito, ed., Transition to Market: Studies in Fiscal Reform. Washington, D.C.: International Monetary Fund, 1993.

Tanzi, Vito, "Quantitative Characteristics of the Tax Systems of Developing Countries," in David Newbery and Nicholas Stern, eds., The Theory of Taxation for Developing Countries, Oxford University Press for the World Bank, Washington, D.C., 1987, 205 - 241.

Treisman, Daniel, "Russia's Tax Crisis: Explaining Falling Revenues in a Transitional Economy," Economics and Politics, 11, 2: 145 - 69, 1999.

Whalley, John, "Distortionary Factor Taxation - A Calculation of Effective Tax Rates in the UK 1968-70," The Manchester School, 43, 1 - 30, 1975. 


\section{APPENDIX}

Table 5: Data Sources for the 25 TEs

\begin{tabular}{|c|c|c|c|c|}
\hline Country & $\begin{array}{c}\text { Tax } \\
\text { Rates }\end{array}$ & Tax Payments & GDP & $\begin{array}{c}\text { Capital and } \\
\text { Labour Income }\end{array}$ \\
\hline Albania & $\begin{array}{l}\text { IBFD; } \\
\text { EBRD }\end{array}$ & IMF1 & IMF2 & NA \\
\hline Bulgaria & $\begin{array}{l}\text { IBFD; } \\
\text { EBRD }\end{array}$ & IMF1 & IMF2 & $\mathrm{NSO}$ \\
\hline Croatia & $\begin{array}{l}\text { IBFD; } \\
\text { ERBD }\end{array}$ & IMF1 & IMF2 & NA \\
\hline Czech Republic & $\begin{array}{l}\text { IBFD; } \\
\text { EBRD }\end{array}$ & IMF1 & IMF2 & $\mathrm{NSO}$ \\
\hline $\begin{array}{l}\text { FYR } \\
\text { Macedonia }\end{array}$ & $\begin{array}{l}\text { IBFD; } \\
\text { EBRD }\end{array}$ & IMF1 & IMF2 & $\mathrm{NA}$ \\
\hline Hungary & $\begin{array}{l}\text { IBFD; } \\
\text { EBRD }\end{array}$ & IMF1 & IMF2 & $\mathrm{NSO}$ \\
\hline Poland & $\begin{array}{l}\text { IBFD; } \\
\text { EBRD }\end{array}$ & IMF1 & IMF2 & $\mathrm{NSO}$ \\
\hline Romania & $\begin{array}{l}\text { IBFD; } \\
\text { EBRD }\end{array}$ & IMF1 & IMF2 & $\mathrm{NSO}$ \\
\hline $\begin{array}{l}\text { Slovak } \\
\text { Republic }\end{array}$ & $\begin{array}{l}\text { IBFD; } \\
\text { EBRD }\end{array}$ & IMF1 & IMF2 & $\mathrm{NSO}$ \\
\hline Slovenia & $\begin{array}{l}\text { IBFD; } \\
\text { EBRD }\end{array}$ & IMF1 & IMF2 & $\mathrm{NSO}$ \\
\hline Armenia & $\begin{array}{l}\text { IBFD; } \\
\text { EBRD }\end{array}$ & IMF1; CIS & IMF2; CIS & CIS \\
\hline Azerbaijan & $\begin{array}{l}\text { IBFD; } \\
\text { EBRD }\end{array}$ & IMF1; CIS & IMF2; CIS & CIS \\
\hline Belarus & $\begin{array}{l}\text { IBFD; } \\
\text { EBRD }\end{array}$ & IMF1; CIS & IMF2; CIS & CIS \\
\hline Estonia & $\begin{array}{l}\text { IBFD; } \\
\text { EBRD }\end{array}$ & IMF1 & IMF2 & $\mathrm{NSO}$ \\
\hline Georgia & $\begin{array}{l}\text { IBFD; } \\
\text { EBRD }\end{array}$ & IMF1: CIS & IMF2; CIS & CIS \\
\hline Kazakhstan & $\begin{array}{l}\text { IBFD; } \\
\text { EBRD }\end{array}$ & IMF1; CIS & IMF2; CIS & CIS \\
\hline Kyrgyzstan & $\begin{array}{l}\text { IBFD; } \\
\text { EBRD }\end{array}$ & IMF1; CIS & IMF2; CIS & CIS \\
\hline Latvia & $\begin{array}{l}\text { IBFD; } \\
\text { EBRD }\end{array}$ & IMF1 & IMF2 & $\mathrm{NSO}$ \\
\hline Lithuania & $\begin{array}{l}\text { IBFD; } \\
\text { EBRD }\end{array}$ & IMF1 & IMF2 & $\mathrm{NSO}$ \\
\hline Moldova & $\begin{array}{l}\text { IBFD; } \\
\text { EBRD }\end{array}$ & IMF1; CIS & IMF2; CIS & CIS \\
\hline Russia & $\begin{array}{l}\text { IBFD; } \\
\text { EBRD }\end{array}$ & IMF1; CIS & IMF2; CIS & CIS \\
\hline
\end{tabular}




\begin{tabular}{|l|c|c|c|c|}
\hline Tajikistan & $\begin{array}{l}\text { IBFD; } \\
\text { EBRD }\end{array}$ & IMF1; CIS & IMF2; CIS & CIS \\
\hline Turkmenistan & $\begin{array}{l}\text { IBFD; } \\
\text { EBRD }\end{array}$ & IMF1; CIS & IMF2; CIS & NA \\
\hline Ukraine & $\begin{array}{l}\text { IBFD; } \\
\text { EBRD }\end{array}$ & IMF1; CIS & IMF2: CIS & CIS \\
\hline Uzbekistan & $\begin{array}{l}\text { IBFD; } \\
\text { EBRD }\end{array}$ & IMF1; CIS & IMF2; CIS & CIS \\
\hline
\end{tabular}

Notes: $\quad$ IBFD $=$ International Bureau of Fiscal Documentation's European Tax Handbook $\mathrm{EBRD}=$ European Bank for Reconstruction and Development's Transition Reports IMF1 = International Monetary Fund's Government Finance Statistics Yearbook (GFSY)* CIS $=$ Statistical Committee of the Commonwealth of Independent States Statistical Yearbook* IMF2 = International Monetary Fund's International Financial Statistics Yearbook* $\mathrm{NSO}=$ various National Statistics Offices' Statistical Bulletin

$\mathrm{NA}=$ Not Available

* An alternate source used is the International Monetary Fund's Staff Country Reports / Recent Economic Developments for the various countries 


\section{Figure 1 Effective Tax Administration and Progress in Transition}

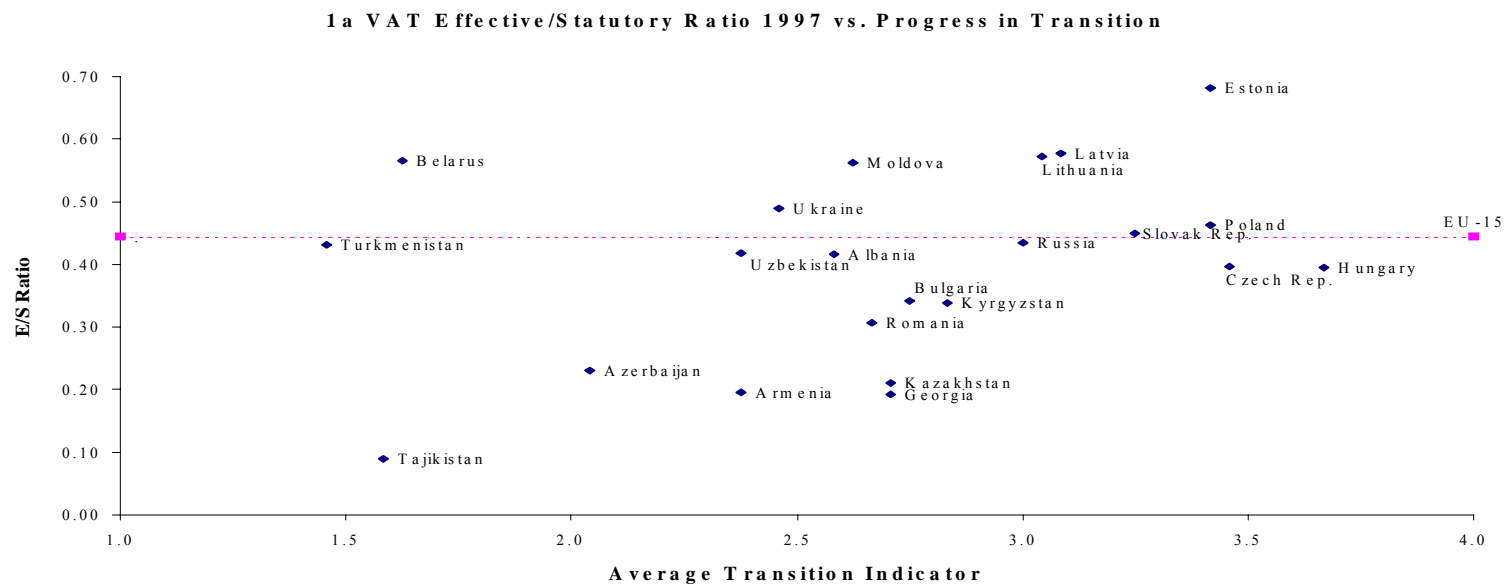

1 b S S T E fective/Statutory Ratio $1997 \mathrm{vs}$. Progress in Transition

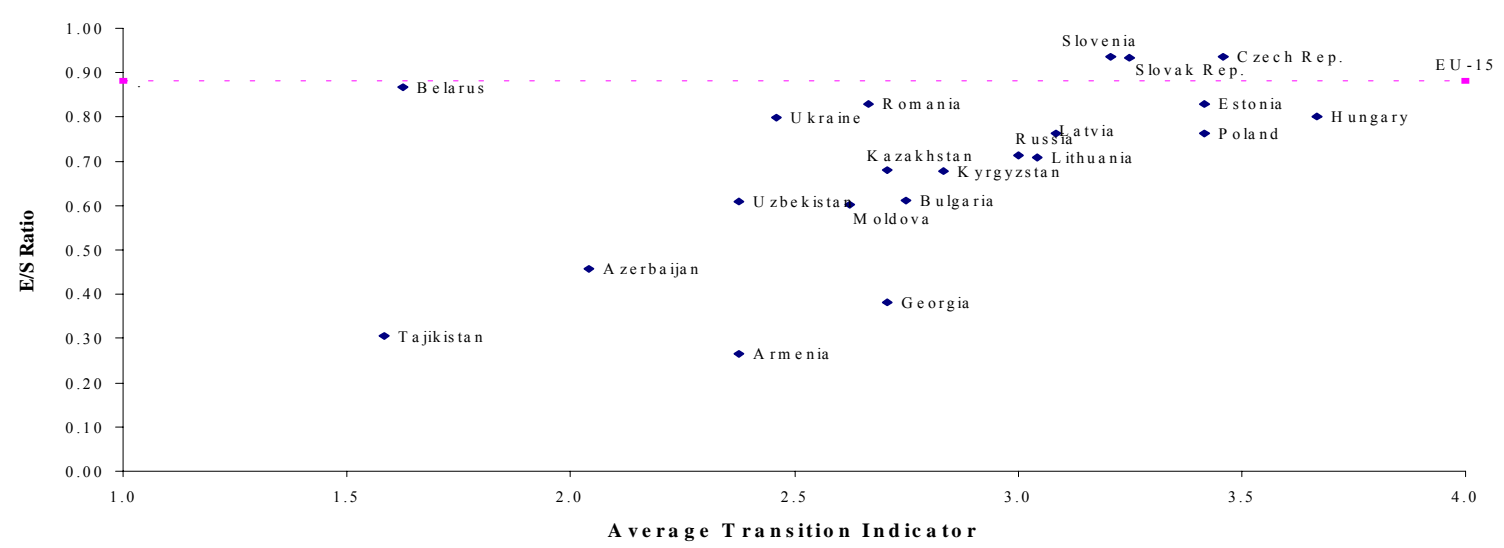

1c CIT Effective/Statutory Ratio 1997 vs. Progress in Transition

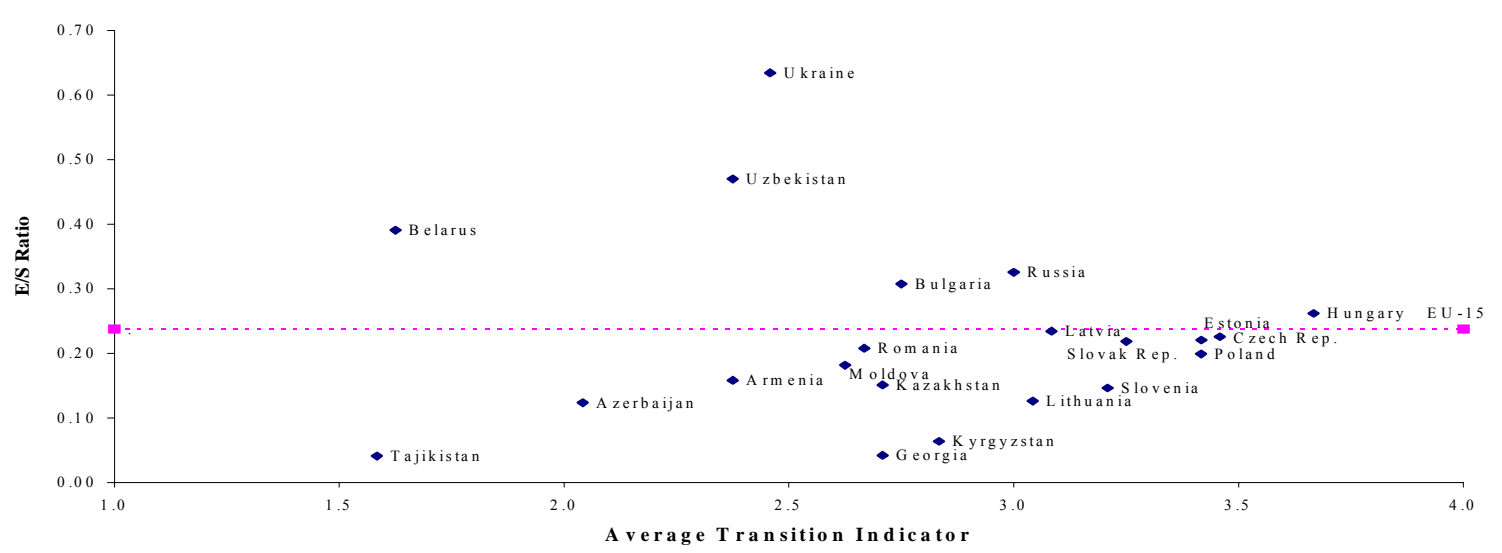


Figure 2 Effective Tax Administration and Progress in Transition

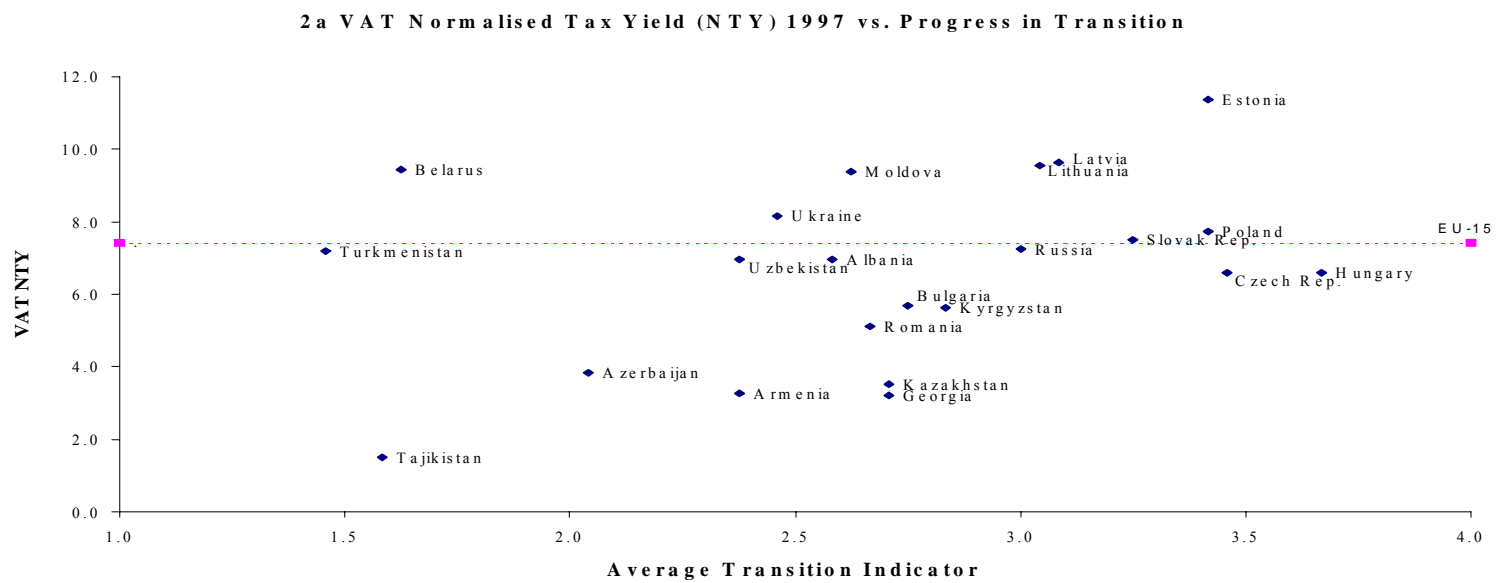

2 b S T N ormalised Tax Yield (N T Y) 1997 vs. Progress in Transition

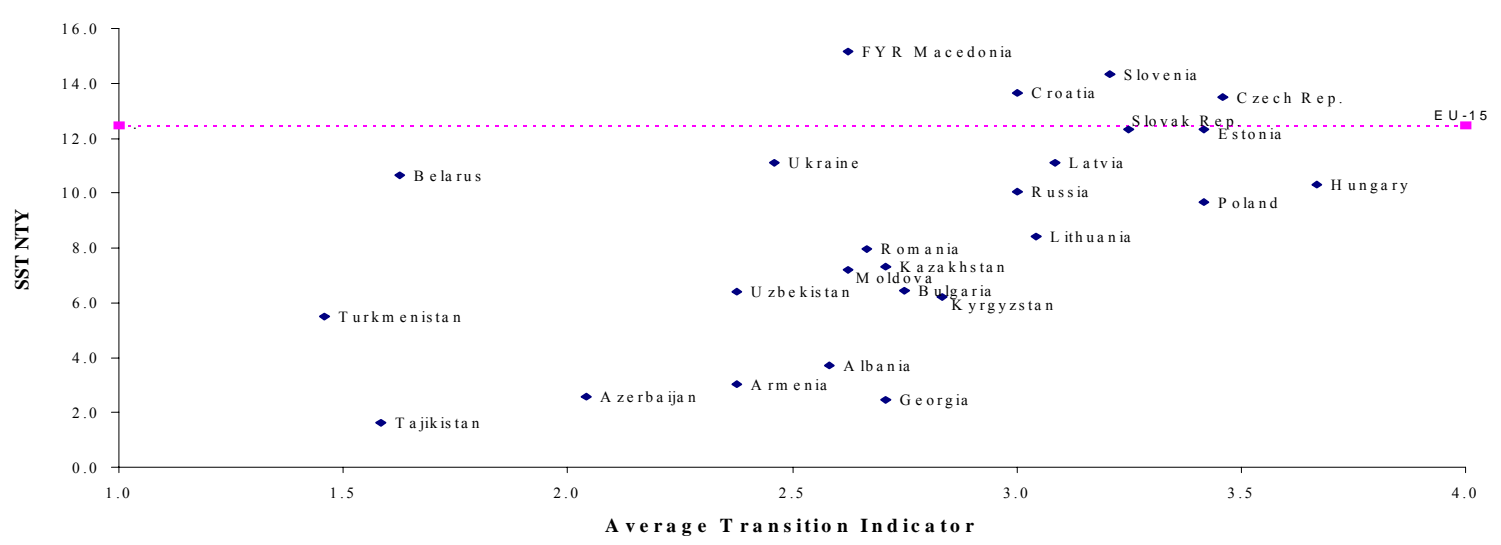

2c CIT Normalised Tax Yield (NTY) 1997 vs. Progress in Transition

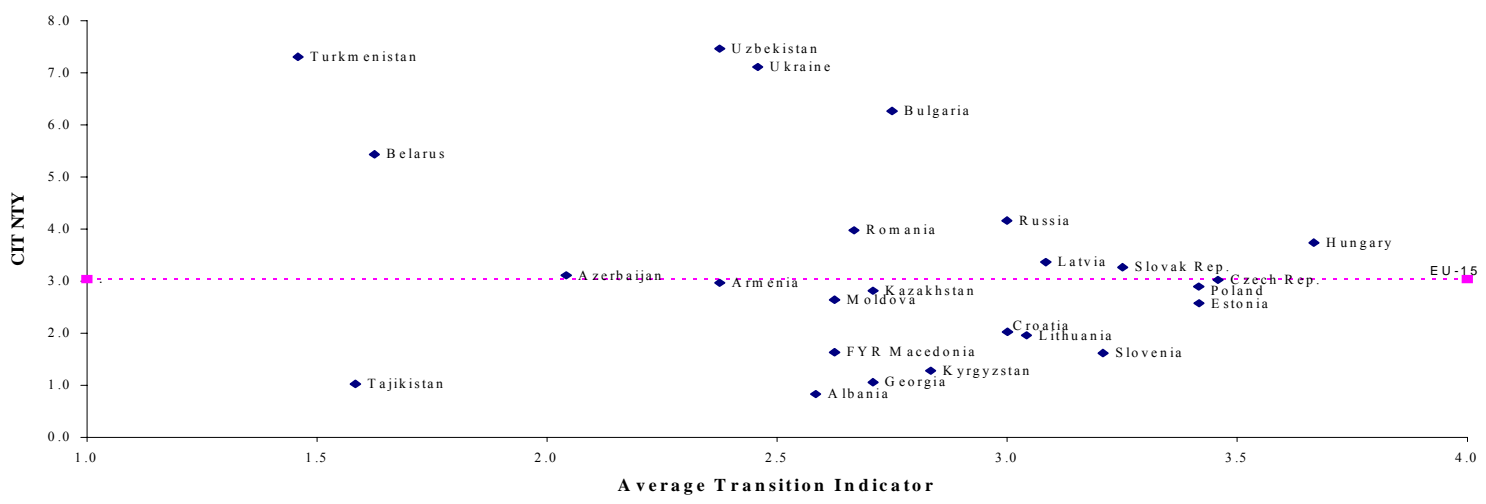




\section{Figure 3 Effective Tax Administration and Bribery}

3a VAT Effective/Statutory Ratio and the Average Bribe Tax

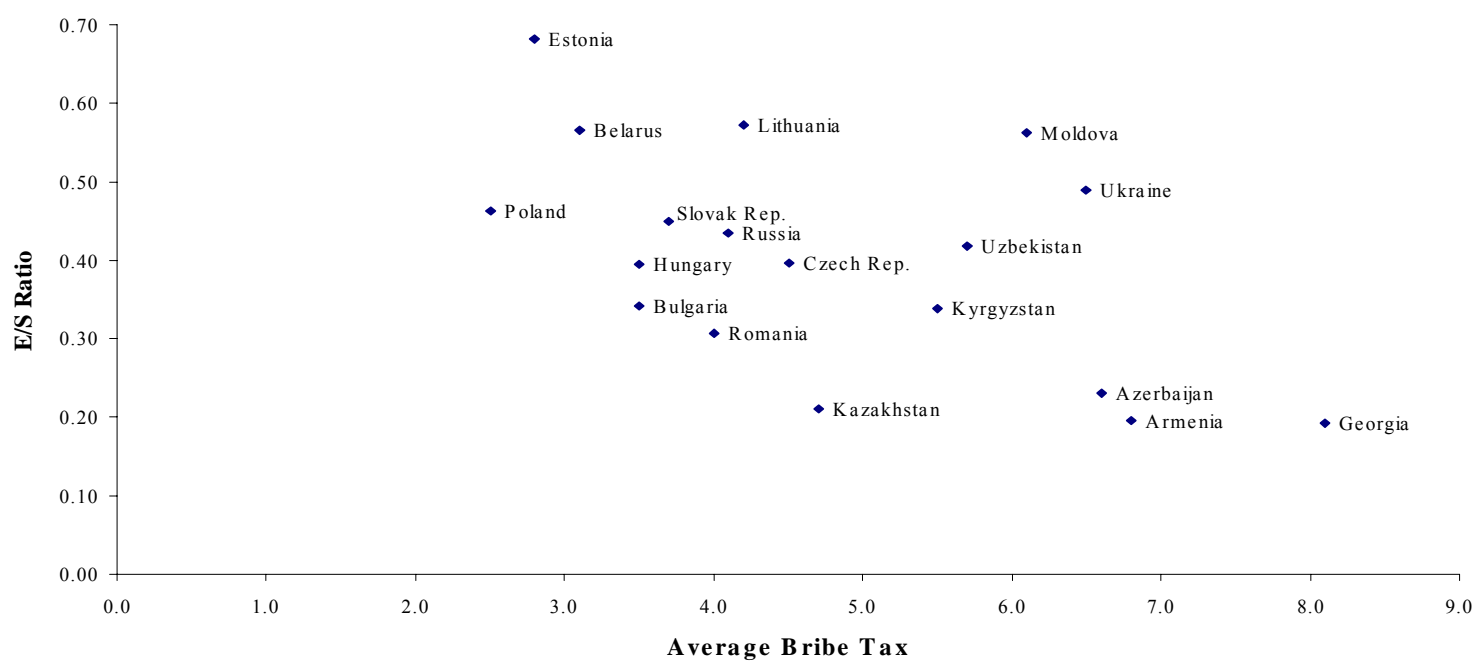

3b SST Effective/Statutory Ratio and the Average Bribe Tax

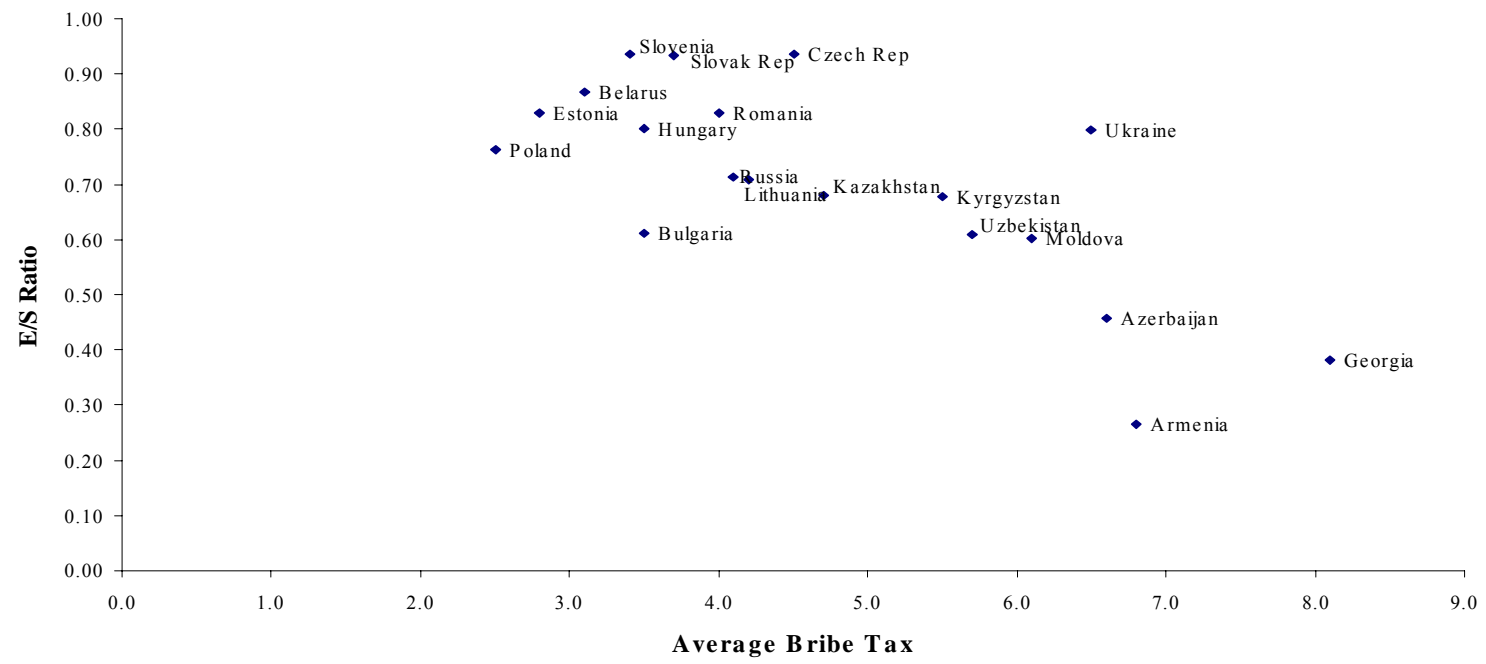




\section{Figure 4 Effective Tax Administration and Bribery}

4a VAT Normalised Tax Yield (NTY) and Average Bribe Tax

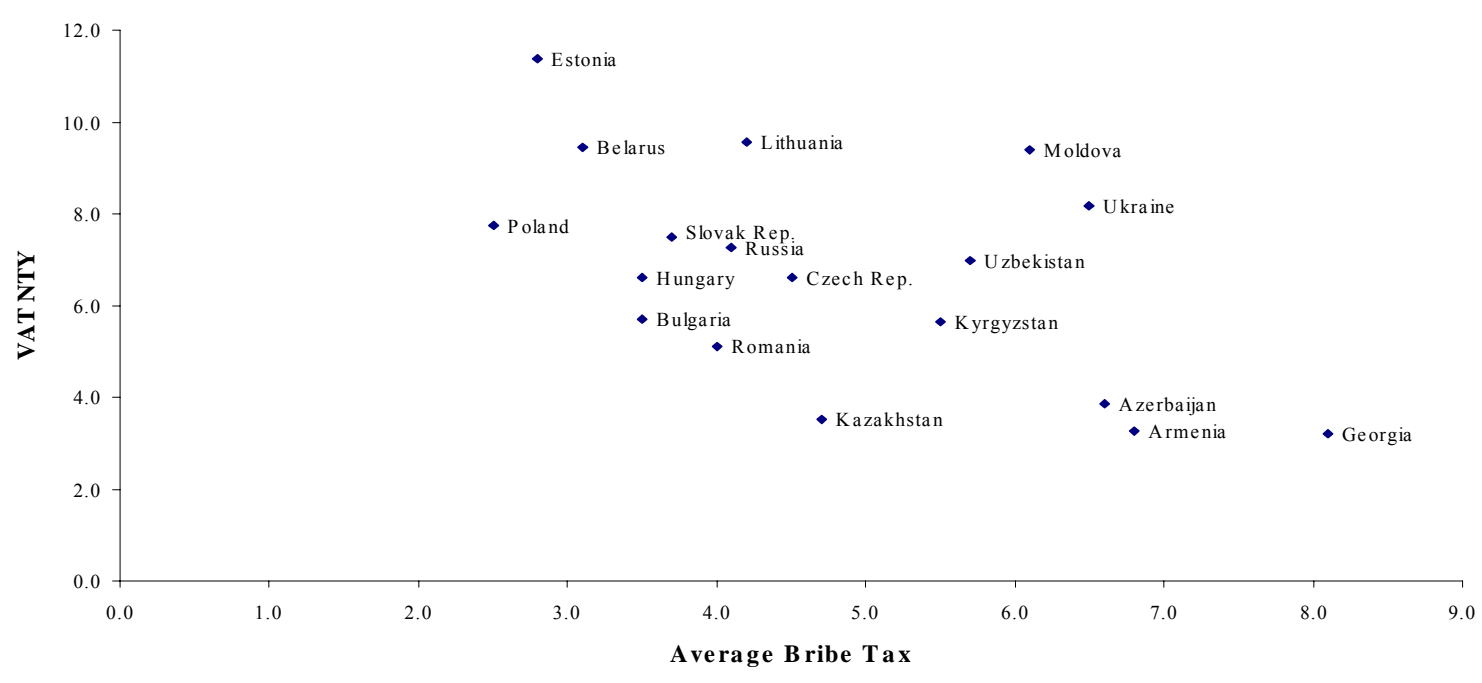

4b SST Normalised Tax Yield ( NTY) and Average B ribe Tax

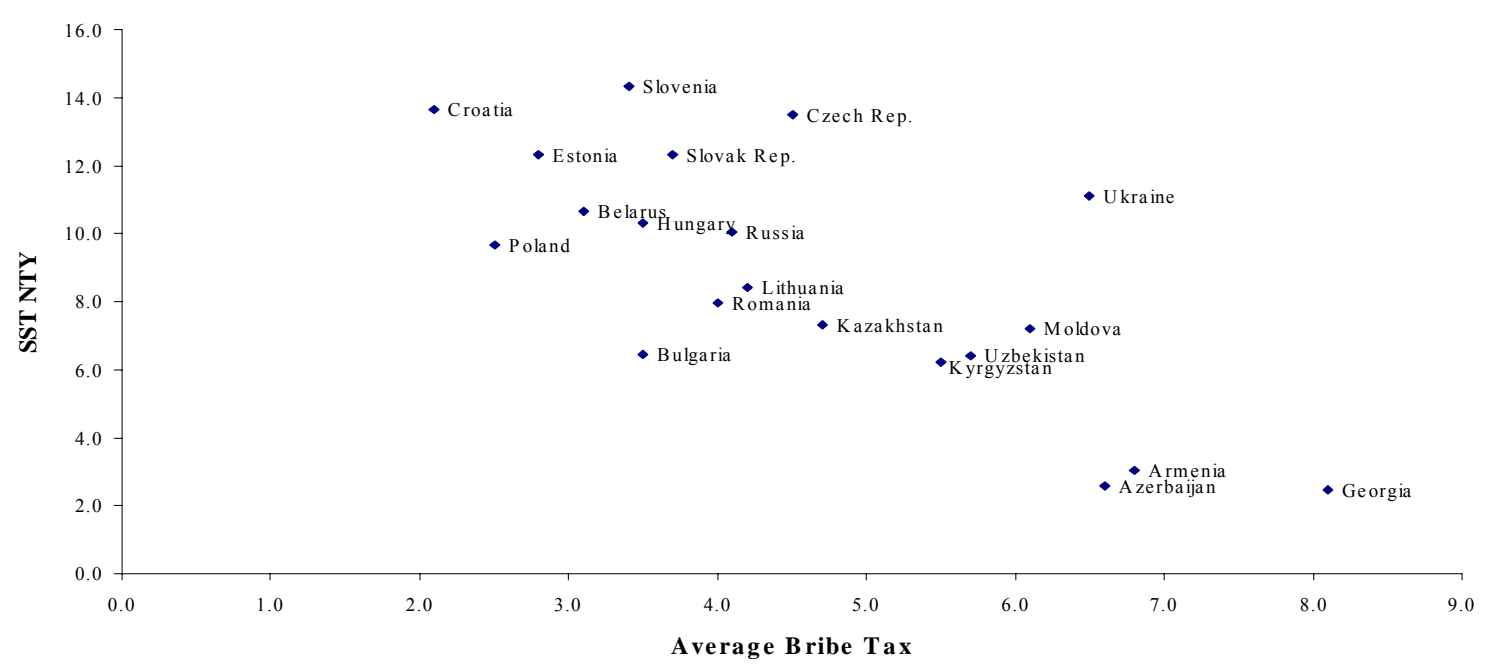




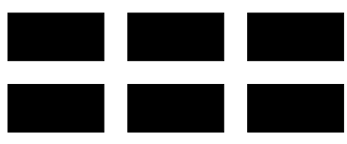

THE WILLIAM DAVIDSON INSTITUTE

AT THE UNIVERSITY OF MICHIGAN BUSINESSSCHOOL

\section{DAVIDSON INSTITUTE WORKING PAPER SERIES}

CURRENT AS OF 11/06/00

\begin{tabular}{|c|c|c|}
\hline Publication & Authors & Date of Paper \\
\hline $\begin{array}{l}\text { No. } 347 \text { Effective versus Statutory Taxation: } \\
\text { Measuring Effective Tax Administration in } \\
\text { Transition Economies }\end{array}$ & Mark E. Schaffer and Gerard Turley & November 2000 \\
\hline $\begin{array}{l}\text { No. } 346 \text { Objectives and Constraints of } \\
\text { Entrepreneurs: Evidence from Small and } \\
\text { Medium Size Enterprises in Russia and } \\
\text { Bulgaria }\end{array}$ & $\begin{array}{l}\text { Francesca Pissarides, Miroslav Singer and } \\
\text { Jan Svejnar }\end{array}$ & October 2000 \\
\hline $\begin{array}{l}\text { No. } 345 \text { Corruption and Anticorruption in the } \\
\text { Czech Republic }\end{array}$ & Lubomír Lízal and Evžen Kočenda & October 2000 \\
\hline $\begin{array}{l}\text { No. } 344 \text { The Effects of Direct Foreign } \\
\text { Investment on Domestic Firms }\end{array}$ & Jozef Konings & October 2000 \\
\hline $\begin{array}{l}\text { No. } 343 \text { On the Identification of Relative } \\
\text { Wage Rigidity Dynamics }\end{array}$ & Patrick A. Puhani & October 2000 \\
\hline $\begin{array}{l}\text { No. } 342 \text { The Determinants of Foreign Direct } \\
\text { Investment in Transition Economies }\end{array}$ & Alan A. Bevan and Saul Estrin & October 2000 \\
\hline $\begin{array}{l}\text { No. } 341 \text { The Global Spread of Stock } \\
\text { Exchanges, 1980-1998 }\end{array}$ & Klaus Weber and Gerald F. Davis & October 2000 \\
\hline $\begin{array}{l}\text { No. } 340 \text { The Costs and Benefits of Euro- } \\
\text { isation in Central-Eastern Europe Before or } \\
\text { Instead of EMU Membership }\end{array}$ & D. Mario Nuti & October 2000 \\
\hline No. 339 Debt Overhang and Barter in Russia & $\begin{array}{l}\text { Sergei Guriev, Igor Makarov and Mathilde } \\
\text { Maurel }\end{array}$ & September 2000 \\
\hline $\begin{array}{l}\text { No. } 338 \text { Firm Performance and the Political } \\
\text { Economy of Corporate Governance: Survey } \\
\text { Evidence for Bulgaria, Hungary, Slovakia and } \\
\text { Slovenia }\end{array}$ & Patrick Paul Walsh and Ciara Whela & July 2000 \\
\hline No. 337 Investment and Instability & Nauro F. Campos and Jeffrey B. Nugent & May 2000 \\
\hline $\begin{array}{l}\text { No. } 336 \text { The Evolution of the Insurance } \\
\text { Sector in Central and Eastern Europe and } \\
\text { the former Soviet Union }\end{array}$ & Robert B.K. Pye & August 2000 \\
\hline $\begin{array}{l}\text { No. } 335 \text { Institutional Technology and the } \\
\text { Chains of Trust: Capital Markets and } \\
\text { Privatization in Russia and the Czech } \\
\text { Republic }\end{array}$ & Bruce Kogut and Andrew Spicer & August 2000 \\
\hline $\begin{array}{l}\text { No. } 334 \text { The Evolution of Market Integration } \\
\text { in Russia }\end{array}$ & Daniel Berkowitz and David N. DeJong & August 2000 \\
\hline $\begin{array}{l}\text { No. } 333 \text { Efficiency and Market Share in } \\
\text { Hungarian Corporate Sector }\end{array}$ & László Halpern and Gábor Körösi & July 2000 \\
\hline $\begin{array}{l}\text { No. } 332 \text { Search-Money-and-Barter Models of } \\
\text { Financial Stabilization }\end{array}$ & S.I. Boyarchenko and S.Z. Levendorskii & July 2000 \\
\hline $\begin{array}{l}\text { No. } 331 \text { Worker Training in a Restructuring } \\
\text { Economy: Evidence from the Russian } \\
\text { Transition }\end{array}$ & $\begin{array}{l}\text { Mark C. Berger, John S. Earle and Klara } \\
\text { Z. Sabirianova }\end{array}$ & August 2000 \\
\hline $\begin{array}{l}\text { No. } 330 \text { Economic Development in Palanpur } \\
\text { 1957-1993: A Sort of Growth }\end{array}$ & Peter Lanjouw & August 2000 \\
\hline No. 329 Trust, Organizational Controls, & Marjorie A. Lyles, Le Dang Doanh, and & June 2000 \\
\hline
\end{tabular}

Working Papers are available at: www.wdi.bus.umich.edu 


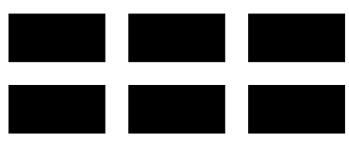

THE WILLIAM DAVIDSON INSTITUTE AT THE UNIVERSITY OF MICHIGAN BUSINESSSCHOOL

\begin{tabular}{|c|c|c|}
\hline $\begin{array}{l}\text { Knowledge Acquisition from the Foreign } \\
\text { Parents, and Performance in Vietnamese } \\
\text { International Joint Ventures }\end{array}$ & Jeffrey Q. Barden & \\
\hline $\begin{array}{l}\text { No. } 328 \text { Comparative Advertising in the } \\
\text { Global Marketplace: The Effects of Cultural } \\
\text { Orientation on Communication }\end{array}$ & $\begin{array}{l}\text { Zeynep Gürhan-Canli and Durairaj } \\
\text { Maheswaran }\end{array}$ & August 2000 \\
\hline $\begin{array}{l}\text { No. } 327 \text { Post Privatization Enterprise } \\
\text { Restructuring }\end{array}$ & Morris Bornstein & July 2000 \\
\hline No. 326 Who is Afraid of Political Instability? & Nauro F. Campos and Jeffrey B. Nugent & July 2000 \\
\hline $\begin{array}{l}\text { No. } 325 \text { Business Groups, the Financial } \\
\text { Market and Modernization }\end{array}$ & Raja Kali & June 2000 \\
\hline $\begin{array}{l}\text { No. } 324 \text { Restructuring with What Success? A } \\
\text { Case Study of Russian Firms }\end{array}$ & Susan Linz & July 2000 \\
\hline $\begin{array}{l}\text { No. } 323 \text { Priorities and Sequencing in } \\
\text { Privatization: Theory and Evidence from the } \\
\text { Czech Republic }\end{array}$ & $\begin{array}{l}\text { Nandini Gupta, John C. Ham and Jan } \\
\text { Svejnar }\end{array}$ & May 2000 \\
\hline $\begin{array}{l}\text { No. } 322 \text { Liquidity, Volatility, and Equity } \\
\text { Trading Costs Across Countries and Over } \\
\text { Time }\end{array}$ & $\begin{array}{l}\text { Ian Domowitz, Jack Glen and Ananth } \\
\text { Madhavan }\end{array}$ & March 2000 \\
\hline $\begin{array}{l}\text { No. } 321 \text { Equilibrium Wage Arrears: } \\
\text { Institutional Lock-In of Contractual Failure in } \\
\text { Russia }\end{array}$ & John S. Earle and Klara Z. Sabirianova & October 2000 \\
\hline $\begin{array}{l}\text { No. } 320 \text { Rethinking Marketing Programs for } \\
\text { Emerging Markets }\end{array}$ & Niraj Dawar and Amitava Chattopadhyay & June 2000 \\
\hline $\begin{array}{l}\text { No. } 319 \text { Public Finance and Low Equilibria in } \\
\text { Transition Economies; the Role of Institutions }\end{array}$ & Daniel Daianu and Radu Vranceanu & June 2000 \\
\hline $\begin{array}{l}\text { No. } 318 \text { Some Econometric Evidence on the } \\
\text { Effectiveness of Active Labour Market } \\
\text { Programmes in East Germany }\end{array}$ & Martin Eichler and Michael Lechner & June 2000 \\
\hline $\begin{array}{l}\text { No. } 317 \text { A Model of Russia’s "Virtual } \\
\text { Economy" }\end{array}$ & R.E Ericson and B.W Ickes & May 2000 \\
\hline $\begin{array}{l}\text { No. } 316 \text { Financial Institutions, Financial } \\
\text { Contagion, and Financial Crises }\end{array}$ & Haizhou Huang and Chenggang $\mathrm{Xu}$ & March 2000 \\
\hline $\begin{array}{l}\text { No. } 315 \text { Privatization versus Regulation in } \\
\text { Developing Economies: The Case of West } \\
\text { African Banks }\end{array}$ & $\begin{array}{l}\text { Jean Paul Azam, Bruno Biais, and } \\
\text { Magueye Dia }\end{array}$ & February 2000 \\
\hline $\begin{array}{l}\text { No. } 314 \text { Is Life More Risky in the Open? } \\
\text { Household Risk-Coping and the Opening of } \\
\text { China's Labor Markets }\end{array}$ & John Giles & April 2000 \\
\hline $\begin{array}{l}\text { No. } 313 \text { Networks, Migration and Investment: } \\
\text { Insiders and Outsiders in Tirupur's Production } \\
\text { Cluster }\end{array}$ & Abhijit Banerjee and Kaivan Munshi & March 2000 \\
\hline $\begin{array}{l}\text { No. } 312 \text { Computational Analysis of the Impact } \\
\text { on India of the Uruguay Round and the } \\
\text { Forthcoming WTO Trade Negotiations }\end{array}$ & $\begin{array}{l}\text { Rajesh Chadha, Drusilla K. Brown, Alan } \\
\text { V. Deardorff and Robert M. Stern }\end{array}$ & March 2000 \\
\hline $\begin{array}{l}\text { No. } 311 \text { Subsidized Jobs for Unemployed } \\
\text { Workers in Slovakia }\end{array}$ & Jan. C. van Ours & May 2000 \\
\hline $\begin{array}{l}\text { No. } 310 \text { Determinants of Managerial Pay in } \\
\text { the Czech Republic }\end{array}$ & $\begin{array}{l}\text { Tor Eriksson, Jaromir Gottvald and Pavel } \\
\text { Mrazek }\end{array}$ & May 2000 \\
\hline $\begin{array}{l}\text { No. } 309 \text { The Great Human Capital } \\
\text { Reallocation: An Empirical Analysis of } \\
\text { Occupational Mobility in Transitional Russia }\end{array}$ & Klara Z. Sabirianova & October 2000 \\
\hline
\end{tabular}

Working Papers are available at:

www.wdi.bus.umich.edu 


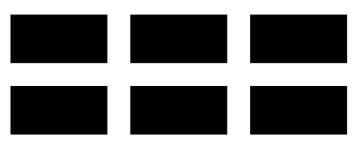

THE WILLIAM DAVIDSON INSTITUTE AT THE UNIVERSITY OF MICHIGAN BUSINESSSCHOOL

\begin{tabular}{|c|c|c|}
\hline $\begin{array}{l}\text { No. } 308 \text { Economic Development, Legality, } \\
\text { and the Transplant Effect }\end{array}$ & $\begin{array}{l}\text { Daniel Berkowitz, Katharina Pistor, and } \\
\text { Jean-Francois Richard }\end{array}$ & February 2000 \\
\hline $\begin{array}{l}\text { No. } 307 \text { Community Participation, Teacher } \\
\text { Effort, and Educational Outcome: The Case of } \\
\text { El Salvador's EDUCO Program }\end{array}$ & Yasuyuki Sawada & November 1999 \\
\hline $\begin{array}{l}\text { No. } 306 \text { Gender Wage Gap and Segregation in } \\
\text { Late Transition }\end{array}$ & Stepan Jurajda & May 2000 \\
\hline $\begin{array}{l}\text { No. } 305 \text { The Gender Pay Gap in the Transition } \\
\text { from Communism: Some Empirical Evidence }\end{array}$ & Andrew Newell and Barry Reilly & May 2000 \\
\hline $\begin{array}{l}\text { No. } 304 \text { Post-Unification Wage Growth in } \\
\text { East Germany }\end{array}$ & Jennifer Hunt & November 1998 \\
\hline $\begin{array}{l}\text { No. } 303 \text { How Does Privatization Affect } \\
\text { Workers? The Case of the Russian Mass } \\
\text { Privatization Program }\end{array}$ & Elizabeth Brainerd & May 2000 \\
\hline $\begin{array}{l}\text { No. } 302 \text { Liability for Past Environmental } \\
\text { Contamination and Privatization }\end{array}$ & Dietrich Earnhart & March 2000 \\
\hline No. 301 Varieties, Jobs and EU Enlargement & Tito Boeri and Joaquim Oliveira Martins & May 2000 \\
\hline No. 300 Employer Size Effects in Russia & Todd Idson & April 2000 \\
\hline $\begin{array}{l}\text { No. } 299 \text { Information Complements, } \\
\text { Substitutes, and Strategic Product Design }\end{array}$ & $\begin{array}{l}\text { Geoffrey G. Parker and Marshall W. Van } \\
\text { Alstyne }\end{array}$ & March 2000 \\
\hline $\begin{array}{l}\text { No. } 298 \text { Markets, Human Capital, and } \\
\text { Inequality: Evidence from Rural China }\end{array}$ & $\begin{array}{l}\text { Dwayne Benjamin, Loren Brandt, Paul } \\
\text { Glewwe, and Li Guo }\end{array}$ & May 2000 \\
\hline $\begin{array}{l}\text { No. } 297 \text { Corporate Governance in the Asian } \\
\text { Financial Crisis }\end{array}$ & $\begin{array}{l}\text { Simon Johnson, Peter Boone, Alasdair } \\
\text { Breach, and Eric Friedman }\end{array}$ & November 1999 \\
\hline $\begin{array}{l}\text { No. } 296 \text { Competition and Firm Performance: } \\
\text { Lessons from Russia }\end{array}$ & J. David Brown and John S. Earle & March 2000 \\
\hline $\begin{array}{l}\text { No. } 295 \text { Wage Determination in Russia: An } \\
\text { Econometric Investigation }\end{array}$ & Peter J. Luke and Mark E. Schaffer & March 2000 \\
\hline $\begin{array}{l}\text { No. 294: Can Banks Promote Enterprise } \\
\text { Restructuring?: Evidence From a Polish } \\
\text { Bank's Experience }\end{array}$ & John P. Bonin and Bozena Leven & March 2000 \\
\hline $\begin{array}{l}\text { No. 293: Why do Governments Sell Privatised } \\
\text { Companies Abroad? }\end{array}$ & $\begin{array}{l}\text { Bernardo Bortolotti, Marcella Fantini and } \\
\text { Carlo Scarpa }\end{array}$ & March 2000 \\
\hline $\begin{array}{l}\text { No. 292: Going Public in Poland: Case-by- } \\
\text { Case Privatizations, Mass Privatization and } \\
\text { Private Sector Initial Public Offerings }\end{array}$ & Wolfgang Aussenegg & December 1999 \\
\hline $\begin{array}{l}\text { No. 291: Institutional Technology and the } \\
\text { Chains of Trust: Capital Markets and } \\
\text { Privatization in Russia and the Czech } \\
\text { Republic }\end{array}$ & Bruce Kogut and Andrew Spicer & March 1999 \\
\hline $\begin{array}{l}\text { No. 290: Banking Crises and Bank Rescues: } \\
\text { The Effect of Reputation }\end{array}$ & Jenny Corbett and Janet Mitchell & January 2000 \\
\hline $\begin{array}{l}\text { No. 289: Do Active Labor Market Policies } \\
\text { Help Unemployed Workers to Find and Keep } \\
\text { Regular Jobs? }\end{array}$ & Jan C. van Ours & February 2000 \\
\hline $\begin{array}{l}\text { No. 288: Consumption Patterns of the New } \\
\text { Elite in Zimbabwe }\end{array}$ & Russell Belk & February 2000 \\
\hline $\begin{array}{l}\text { No. 287: Barter in Transition Economies: } \\
\text { Competing Explanations Confront Ukranian } \\
\text { Data }\end{array}$ & $\begin{array}{l}\text { Dalia Marin, Daniel Kaufmann and } \\
\text { Bogdan Gorochowskij }\end{array}$ & January 2000 \\
\hline No. 286: The Quest for Pension Reform: & Marek Góra and Michael Rutkowski & January 2000 \\
\hline
\end{tabular}

Working Papers are available at: www.wdi.bus.umich.edu 


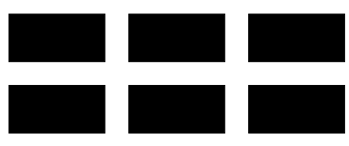

THE WILLIAM DAVIDSON INSTITUTE AT THE UNIVERSITY OF MICHIGAN BUSINESSSCHOOL

\begin{tabular}{|c|c|c|}
\hline Poland's Security through Diversity & & \\
\hline $\begin{array}{l}\text { No. 285: Disorganization and Financial } \\
\text { Collapse }\end{array}$ & Dalia Marin and Monika Schnitzer & October 1999 \\
\hline $\begin{array}{l}\text { No. 284: Coordinating Changes in M-form } \\
\text { and U-form Organizations }\end{array}$ & $\begin{array}{l}\text { Yingyi Qian, Gérard Roland and } \\
\text { Chenggang Xu }\end{array}$ & May 1999 \\
\hline $\begin{array}{l}\text { No. 283: Why Russian Workers Do Not } \\
\text { Move: Attachment of Workers Through In- } \\
\text { Kind Payments }\end{array}$ & Guido Friebel and Sergei Guriev & October 1999 \\
\hline $\begin{array}{l}\text { No. 282: Lessons From Fiascos in Russian } \\
\text { Corporate Governance }\end{array}$ & Merritt B. Fox and Michael A. Heller & October 1999 \\
\hline $\begin{array}{l}\text { No. 281: Income Distribution and Price } \\
\text { Controls: Targeting a Social Safety Net } \\
\text { During Economic Transition }\end{array}$ & Michael Alexeev and James Leitzel & March 1999 \\
\hline $\begin{array}{l}\text { No. 280: Starting Positions, Reform Speed, } \\
\text { and Economic Outcomes in Transitioning } \\
\text { Economies }\end{array}$ & William Hallagan and Zhang Jun & January 2000 \\
\hline No. 279: The Value of Prominent Directors & Yoshiro Miwa \& J. Mark Ramseyer & October 1999 \\
\hline No. 278: The System Paradigm & János Kornai & April 1998 \\
\hline $\begin{array}{l}\text { No. 277: The Developmental Consequences of } \\
\text { Foreign Direct Investment in the Transition } \\
\text { from Socialism to Capitalism: The } \\
\text { Performance of Foreign Owned Firms in } \\
\text { Hungary }\end{array}$ & Lawrence Peter King & September 1999 \\
\hline $\begin{array}{l}\text { No. 276: Stability and Disorder: An } \\
\text { Evolutionary Analysis of Russia's Virtual } \\
\text { Economy }\end{array}$ & Clifford Gaddy and Barry W. Ickes & November 1999 \\
\hline $\begin{array}{l}\text { No. 275: Limiting Government Predation } \\
\text { Through Anonymous Banking: A Theory with } \\
\text { Evidence from China. }\end{array}$ & $\begin{array}{l}\text { Chong-En Bai, David D. Li, Yingyi Qian } \\
\text { and Yijiang Wang }\end{array}$ & July 1999 \\
\hline No. 274: Transition with Labour Supply & Tito Boeri & December 1999 \\
\hline $\begin{array}{l}\text { No. 273: Sectoral Restructuring and Labor } \\
\text { Mobility: A Comparative Look at the Czech } \\
\text { Republic }\end{array}$ & Vit Sorm and Katherine Terrell & November 1999 \\
\hline $\begin{array}{l}\text { No. 272: Published in: Journal of Comparative } \\
\text { Economics "Returns to Human Capital Under } \\
\text { the Communist Wage Grid and During the } \\
\text { Transition to a Market Economy" Vol. 27, pp. } \\
\text { 33-60 1999. }\end{array}$ & $\begin{array}{l}\text { Daniel Munich, Jan Svejnar and Katherine } \\
\text { Terrell }\end{array}$ & October 1999 \\
\hline $\begin{array}{l}\text { No. 271: Barter in Russia: Liquidity Shortage } \\
\text { Versus Lack of Restructuring }\end{array}$ & Sophie Brana and Mathilde Maurel & June 1999 \\
\hline $\begin{array}{l}\text { No. 270: Tests for Efficient Financial } \\
\text { Intermediation with Application to China }\end{array}$ & Albert Park and Kaja Sehrt & March 1999 \\
\hline $\begin{array}{l}\text { No. 269a: Russian Privatization and Corporate } \\
\text { Governance: What Went Wrong? }\end{array}$ & $\begin{array}{l}\text { Bernard Black, Reinier Kraakman and } \\
\text { Anna Tarassova }\end{array}$ & May 2000 \\
\hline $\begin{array}{l}\text { No. 269: Russian Privatization and Corporate } \\
\text { Governance: What Went Wrong? }\end{array}$ & $\begin{array}{l}\text { Bernard Black, Reinier Kraakman and } \\
\text { Anna Tarassova }\end{array}$ & September 1999 \\
\hline $\begin{array}{l}\text { No. 268: Are Russians Really Ready for } \\
\text { Capitalism? }\end{array}$ & Susan Linz & September 1999 \\
\hline $\begin{array}{l}\text { No. 267: Do Stock Markets Promote } \\
\text { Economic Growth? }\end{array}$ & $\begin{array}{l}\text { Randall K. Filer, Jan Hanousek and Nauro } \\
\text { Campos }\end{array}$ & September 1999 \\
\hline
\end{tabular}

Working Papers are available at: www.wdi.bus.umich.edu 


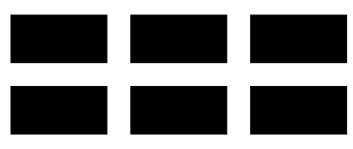

THE WILLIAM DAVIDSON INSTITUTE AT THE UNIVERSITY OF MICHIGAN BUSINESSSCHOOL

\begin{tabular}{|c|c|c|}
\hline $\begin{array}{l}\text { No. 266: Objectivity, Proximity and } \\
\text { Adaptability in Corporate Governance }\end{array}$ & Arnoud W.A Boot and Jonathan R. Macey & September 1999 \\
\hline $\begin{array}{l}\text { No. 265: When the Future is not What it Used } \\
\text { to Be: Lessons from the Western European } \\
\text { Experience to Forecasting Education and } \\
\text { Training in Transitional Economies }\end{array}$ & $\begin{array}{l}\text { Nauro F. Campos, Gerard Hughes, Stepan } \\
\text { Jurajda, and Daniel Munich }\end{array}$ & September 1999 \\
\hline $\begin{array}{l}\text { No. 264: The Institutional Foundation of } \\
\text { Foreign-Invested Enterprises (FIEs) in China }\end{array}$ & Yasheng Huang & September 1999 \\
\hline $\begin{array}{l}\text { No. 263: The Changing Corporate Governance } \\
\text { Paradigm: Implications for Transition and } \\
\text { Developing Countries }\end{array}$ & $\begin{array}{l}\text { Erik Berglof and Ernst-Ludwig von } \\
\text { Thadden }\end{array}$ & June 1999 \\
\hline No. 262: Law Enforcement and Transition & Gerard Roland and Thierry Verdier & May 1999 \\
\hline $\begin{array}{l}\text { No. 261: Soft Budget Constraints, Pecuniary } \\
\text { Externality, and the Dual Track System }\end{array}$ & Jiahua Che & June 2000 \\
\hline $\begin{array}{l}\text { No. 260: Missing Market in Labor Quality: } \\
\text { The Role of Quality Markets in Transition }\end{array}$ & Gary H. Jefferson & July 1999 \\
\hline $\begin{array}{l}\text { No. 259: Do Corporate Global Environmental } \\
\text { Standards in Emerging Markets Create or } \\
\text { Destroy Market Value }\end{array}$ & $\begin{array}{l}\text { Glen Dowell, Stuart Hart and Bernard } \\
\text { Yeung }\end{array}$ & June 1999 \\
\hline $\begin{array}{l}\text { No. 258: Public Training and Outflows from } \\
\text { Unemployment }\end{array}$ & Patrick A. Puhani & June 1999 \\
\hline $\begin{array}{l}\text { No. 257: Ownership Versus Environment: } \\
\text { Why are Public Sector Firms Inefficient? }\end{array}$ & Ann P. Bartel and Ann E. Harrison & June 1999 \\
\hline $\begin{array}{l}\text { No. 256: Taxation and Evasion in the Presence } \\
\text { of Exortion by Organized Crime }\end{array}$ & $\begin{array}{l}\text { Michael Alexeev, Eckhard Janeba and } \\
\text { Stefan Osborne }\end{array}$ & November 1999 \\
\hline $\begin{array}{l}\text { No. 255: Revisiting Hungary's Bankruptcy } \\
\text { Episode }\end{array}$ & John P. Bonin and Mark E. Schaffer & September 1999 \\
\hline $\begin{array}{l}\text { No. 254: FDI in Emerging Markets: A Home- } \\
\text { Country View }\end{array}$ & Marina v.N Whitman & June 1999 \\
\hline $\begin{array}{l}\text { No. 253: The Asian Financial Crisis: What } \\
\text { Happened, and What is to be Done }\end{array}$ & Jeffrey D. Sachs and Wing Thye Woo & January 1999 \\
\hline $\begin{array}{l}\text { No. 252: Organizational Law as Asset } \\
\text { Partitioning }\end{array}$ & Henry Hansmann and Reinier Kraakman & September 1999 \\
\hline $\begin{array}{l}\text { No. 251: Consumer Behavior Research in } \\
\text { Emerging Consumer Markets: the Case of the } \\
\text { Optimum Stimulation Level in South Africa }\end{array}$ & $\begin{array}{l}\text { Jan-Benedict E. M. Steenkamp and Steven } \\
\text { M. Burgess }\end{array}$ & September 1999 \\
\hline $\begin{array}{l}\text { No. 250: Property Rights Formation and the } \\
\text { Organization of Exchange and Production in } \\
\text { Rural China }\end{array}$ & $\begin{array}{l}\text { Matthew A. Turner, Loren Brandt, and } \\
\text { Scott Rozelle }\end{array}$ & July 1998 \\
\hline $\begin{array}{l}\text { No. 249: Impacts of the Indonesian Economic } \\
\text { Crisis: Price Changes and the Poor }\end{array}$ & $\begin{array}{l}\text { James Levinsohn, Steven Berry, and Jed } \\
\text { Friedman }\end{array}$ & June 1999 \\
\hline $\begin{array}{l}\text { No. 248: Internal Barriers in the Transition of } \\
\text { Enterprises from Central Plan to Market }\end{array}$ & Charalambos Vlachoutsicos & July 1999 \\
\hline $\begin{array}{l}\text { No. 247: Spillovers from Multinationals in } \\
\text { Developing Countries: the Mechanisms at } \\
\text { Work }\end{array}$ & Richard E. Caves & June 1999 \\
\hline $\begin{array}{l}\text { No. 246: Dynamism and Inertia on the } \\
\text { Russian Labour Market: A Model of } \\
\text { Segmentation }\end{array}$ & $\begin{array}{l}\text { Irena Grosfeld, Claudia Senik-Leygonie, } \\
\text { Thierry Verdier, Stanislav Kolenikov and } \\
\text { Elena Paltseva }\end{array}$ & May 1999 \\
\hline $\begin{array}{l}\text { No. 245: Lessons from Bank Privatization in } \\
\text { Central Europe }\end{array}$ & John Bonin and Paul Wachtel & May 1999 \\
\hline No. 244: Nominal-Real Tradeoffs and the & Christian Popa & December 1998 \\
\hline
\end{tabular}

Working Papers are available at:

www.wdi.bus.umich.edu 


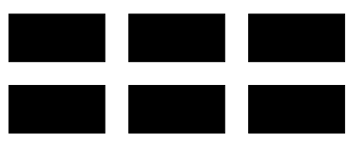

THE WILLIAM DAVIDSON INSTITUTE AT THE UNIVERSITY OF MICHIGAN BUSINESSSCHOOL

\begin{tabular}{|c|c|c|}
\hline $\begin{array}{l}\text { Effects of Monetary Policy: the Romanian } \\
\text { Experience }\end{array}$ & & \\
\hline $\begin{array}{l}\text { No. 243: Privatization, Political Risk and } \\
\text { Stock Market Development in Emerging } \\
\text { Economies }\end{array}$ & Enrico C. Perotti and Pieter van Oijen & March 1999 \\
\hline $\begin{array}{l}\text { No. 242: Investment Financing in Russian } \\
\text { Financial-Industrial Groups }\end{array}$ & Enrico C. Perotti and Stanislav Gelfer & October 1998 \\
\hline $\begin{array}{l}\text { No. 241: Can governments maintain hard } \\
\text { budget constraints? Bank lending and } \\
\text { financial isolation in Romania }\end{array}$ & $\begin{array}{l}\text { Octavian Carare, Constantijn Claessens, } \\
\text { Enrico C. Perotti }\end{array}$ & January 1999 \\
\hline $\begin{array}{l}\text { No. 240: Democratic Institutions and } \\
\text { Economic Reform: the Polish Case }\end{array}$ & $\begin{array}{l}\text { John E. Jackson, Jacek Klich, and } \\
\text { Krystyna Poznanska }\end{array}$ & April 1998 \\
\hline $\begin{array}{l}\text { No. 239: A Longitudinal Study of IJV } \\
\text { Performance in Eastern Europe }\end{array}$ & Keith D. Brouthers and Gary Bamossy & June 1999 \\
\hline $\begin{array}{l}\text { No. 238: Published in: Journal of Business } \\
\text { Venturing, "Firm Creation and Economic } \\
\text { Transitions" Vol. 14, Iss. 5,6 Sep/Nov 1999, } \\
\text { pp. 427-450. }\end{array}$ & $\begin{array}{l}\text { John E. Jackson, Jacek Klich, Krystyna } \\
\text { Poznanska }\end{array}$ & July 1998 \\
\hline $\begin{array}{l}\text { No. 237: Analysis of Entrepreneurial Attitudes } \\
\text { in Poland }\end{array}$ & $\begin{array}{l}\text { John E. Jackson and Aleksander S. } \\
\text { Marcinkowski }\end{array}$ & March 1997 \\
\hline $\begin{array}{l}\text { No. 236: Investment and Finance in De Novo } \\
\text { Private Firms: Empirical Results from the } \\
\text { Czech Republic, Hungary, and Poland }\end{array}$ & $\begin{array}{l}\text { Andrzej Bratkowski, Irena Grosfeld, Jacek } \\
\text { Rostowski }\end{array}$ & April 1999 \\
\hline $\begin{array}{l}\text { No. 235: Does a Soft Macroeconomic } \\
\text { Environment Induce Restructuring on the } \\
\text { Microeconomic Level during the Transition } \\
\text { Period? Evidence from Investment Behavior } \\
\text { of Czech Enterprises }\end{array}$ & Lubomír Lízal & June 1999 \\
\hline $\begin{array}{l}\text { No. 234: Banking Reform in China: Gradually } \\
\text { Strengthening Pillar or Fragile Reed? }\end{array}$ & John Bonin & June 1999 \\
\hline $\begin{array}{l}\text { No. 233: Theories of Soft Budget Constraints } \\
\text { and the Analysis of Banking Crises }\end{array}$ & Janet Mitchell & March 1999 \\
\hline $\begin{array}{l}\text { No. 232: Unemployment Risk, Precautionary } \\
\text { Savings, and Moonlighting in Russia }\end{array}$ & $\begin{array}{l}\text { Alessandra Guariglia and Byung-Yeon } \\
\text { Kim }\end{array}$ & June 1999 \\
\hline $\begin{array}{l}\text { No. 231: Investing in Turbulent Times: The } \\
\text { Investment Behavior of Polish Firms in the } \\
\text { Transition }\end{array}$ & $\begin{array}{l}\text { Josef C. Brada, Arthur E. King, and Chia- } \\
\text { Ying Ma }\end{array}$ & April 1999 \\
\hline $\begin{array}{l}\text { No. 230: The End of Moderate Inflation in } \\
\text { Three Transition Economies? }\end{array}$ & Josef C. Brada and Ali M. Kutan & April 1999 \\
\hline $\begin{array}{l}\text { No. 229: Back to the Future: The Growth } \\
\text { Prospects of Transition Economies } \\
\text { Reconsidered }\end{array}$ & Nauro F. Campos & April 1999 \\
\hline $\begin{array}{l}\text { No. 228: The Enterprise Isolation Program in } \\
\text { Russia }\end{array}$ & Simeon Djankov & April 1999 \\
\hline $\begin{array}{l}\text { No. 227: Published in: Journal of Comparative } \\
\text { Economics, "Ownership Concentration and } \\
\text { Corporate Performance in the Czech } \\
\text { Republic" 27(3), September 1999, pp. 498- } \\
\text { 513. }\end{array}$ & Stijn Claessens and Simeon Djankov & April 1999 \\
\hline $\begin{array}{l}\text { No. 226: Unemployment Benefit Entitlement } \\
\text { and Training Effects in Poland during } \\
\text { Transition }\end{array}$ & Patrick A. Puhani & March 1999 \\
\hline
\end{tabular}

Working Papers are available at: www.wdi.bus.umich.edu 


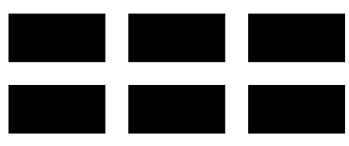

THE WILLIAM DAVIDSON INSTITUTE AT THE UNIVERSITY OF MICHIGAN BUSINESSSCHOOL

\begin{tabular}{|c|c|c|}
\hline $\begin{array}{l}\text { No. 225: Transition at Whirlpool-Tatramat: } \\
\text { Case Studies }\end{array}$ & Hans Brechbuhl and Sonia Ferencikova & March 1999 \\
\hline $\begin{array}{l}\text { No. 224: Measuring Progress in Transition } \\
\text { and Towards EU Accession: A Comparison } \\
\text { of Manufacturing Firms in Poland, Romania, } \\
\text { and Spain }\end{array}$ & $\begin{array}{l}\text { Wendy Carlin, Saul Estrin, and Mark } \\
\text { Schaffer }\end{array}$ & March 1999 \\
\hline $\begin{array}{l}\text { No. 223: Product Market Competition in } \\
\text { Transition Economies: Increasing Varieties } \\
\text { and Consumer Loyalty }\end{array}$ & Mitsutoshi M. Adachi & March 1999 \\
\hline $\begin{array}{l}\text { No. 222: Opaque Markets and Rapid Growth: } \\
\text { the Superiority of Bank-Centered Financial } \\
\text { Systems for Developing Nations }\end{array}$ & Rodney Wallace & July 1999 \\
\hline $\begin{array}{l}\text { No. 221: Technology Spillovers through } \\
\text { Foreign Direct Investment }\end{array}$ & Yuko Kinoshita & January 1999 \\
\hline $\begin{array}{l}\text { No. 220: Managerial, Expertise and Team } \\
\text { Centered Forms of Organizing: A Cross- } \\
\text { Cultural Exploration of Independence in } \\
\text { Engineering Work }\end{array}$ & Leslie Perlow & January 1999 \\
\hline $\begin{array}{l}\text { No. 219: Household Structure and Labor } \\
\text { Demand in Agriculture: Testing for } \\
\text { Separability in Rural China }\end{array}$ & Audra J. Bowlus and Terry Sicular & January 1999 \\
\hline $\begin{array}{l}\text { No. 218: Competing Strategies of FDI and } \\
\text { Technology Transfer to China: American and } \\
\text { Japanese Firms }\end{array}$ & W. Mark Fruin and Penelope Prime & January 1999 \\
\hline $\begin{array}{l}\text { No. } 217 \text { Published in: Journal of Comparative } \\
\text { Economics, "Returns to Mobility in the } \\
\text { Transition to a Market Economy" Vol. 27, No. } \\
\text { 1, March 1999, pp. 4- }\end{array}$ & Tito Boeri and Christopher J. Flinn & January 1999 \\
\hline $\begin{array}{l}\text { No. } 216 \text { Published in: Journal of Comparative } \\
\text { Economics, "Labor Market Policies and } \\
\text { Unemployment in the Czech Republic." Vol. } \\
\text { 27, No. 1, March 1999, pp. 33-60. }\end{array}$ & Katherine Terrell and Vit Sorm & November 1998 \\
\hline $\begin{array}{l}\text { No. } 215 \text { Published in: Journal of Comparative } \\
\text { Economics, “Active Labor Market Policies in } \\
\text { Poland: Human Capital Enhancement, } \\
\text { Stigmatization or Benefit Churning?" Vol. 27, } \\
\text { No. 1, March 1999, pp. 61- }\end{array}$ & $\begin{array}{l}\text { Jochen Kluve, Hartmut Lehmann, and } \\
\text { Christoph M. Schmidt }\end{array}$ & December 1998 \\
\hline $\begin{array}{l}\text { No. } 214 \text { Published in: Journal of Comparative } \\
\text { Economics, "Does the Slovenian Public Work } \\
\text { Program Increase Participants' Chances to } \\
\text { Find a Job?" Vol. 27, No.1, March 1999, pp. } \\
\text { 113- }\end{array}$ & Milan Vodopivec & December 1998 \\
\hline $\begin{array}{l}\text { No. } 213 \text { Published in: Journal of Comparative } \\
\text { Economics, "Effects of Active Labor Market } \\
\text { Programs on the Transition Rate from } \\
\text { Unemployment into Regular Jobs in the } \\
\text { Slovak Republic." Vol. 27, No. 1, March } \\
\text { 1999, pp. 90- }\end{array}$ & Martina Lubyova and Jan C. van Ours & December 1998 \\
\hline $\begin{array}{l}\text { No. 212: The Marketing System in Bulgarian } \\
\text { Livestock Production - The Present State and } \\
\text { Evolutionary Processes During the Period of } \\
\text { Economic Transition }\end{array}$ & Yordan Staykov, Team Leader & October 1998 \\
\hline
\end{tabular}

Working Papers are available at: www.wdi.bus.umich.edu 


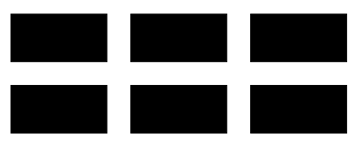

THE WILLIAM DAVIDSON INSTITUTE AT THE UNIVERSITY OF MICHIGAN BUSINESSSCHOOL

\begin{tabular}{|c|c|c|}
\hline $\begin{array}{l}\text { No. 211: Bankruptcy Experience in Hungary } \\
\text { and the Czech Republic }\end{array}$ & Janet Mitchell & October 1998 \\
\hline $\begin{array}{l}\text { No 210: Values, Optimum Stimulation Levels } \\
\text { and Brand Loyalty: New Scales in New } \\
\text { Populations }\end{array}$ & Steven M. Burgess and Mari Harris & September 1998 \\
\hline $\begin{array}{l}\text { No. 209: Inherited Wealth, Corporate Control } \\
\text { and Economic Growth }\end{array}$ & $\begin{array}{l}\text { Randall K. Morck, David A. Stangeland, } \\
\text { and Bernard Yeung }\end{array}$ & September 1998 \\
\hline $\begin{array}{l}\text { No. 208: A Cultural Analysis of Homosocial } \\
\text { Reproduction and Contesting Claims to } \\
\text { Competence in Transitional Firms }\end{array}$ & Michael D. Kennedy & July 1998 \\
\hline $\begin{array}{l}\text { No. 207: From Survival to Success: The } \\
\text { Journey of Corporate Transformation at Haier. } \\
\text { Forthcoming in Teaching the Dinosaurs to } \\
\text { Dance: Organizational Change in Transition } \\
\text { Economies ed. Daniel Denison. }\end{array}$ & Arthur Yeung and Kenneth DeWoskin & July 1998 \\
\hline $\begin{array}{l}\text { No. 206: Why Do People Work If They Are } \\
\text { Not Paid? An Example from Eastern Europe. } \\
\text { Forthcoming in Teaching the Dinosaurs to } \\
\text { Dance: Organizational Change in Transition } \\
\text { Economies ed. Daniel Denison. }\end{array}$ & Irina L. Zinovieva & May 1998 \\
\hline $\begin{array}{l}\text { No. 205: Firm Ownership and Work } \\
\text { Motivation in Bulgaria and Hungary: An } \\
\text { Empirical Study of the Transition in the Mid- } \\
\text { 1990s. Forthcoming in Teaching the } \\
\text { Dinosaurs to Dance: Organizational Change in } \\
\text { Transition Economies ed. Daniel Denison. }\end{array}$ & $\begin{array}{l}\text { Robert A. Roe, Irina L. Zinovieva, } \\
\text { Elizabeth Dienes, and Laurens A. ten Horn }\end{array}$ & May 1998 \\
\hline $\begin{array}{l}\text { No. 204: Human Resource Management in the } \\
\text { Restructuring of Chinese Joint Ventures. } \\
\text { Forthcoming in Teaching the Dinosaurs to } \\
\text { Dance: Organizational Change in Transition } \\
\text { Economies ed. Daniel Denison. }\end{array}$ & Nandani Lynton & April 1998 \\
\hline $\begin{array}{l}\text { No. 203: Emergent Compensation Strategies } \\
\text { in Post-Socialist Poland: Understanding the } \\
\text { Cognitive Underpinnings of Management } \\
\text { Practices in a Transition Economy. } \\
\text { Forthcoming in Teaching the Dinosaurs to } \\
\text { Dance: Organizational Change in Transition } \\
\text { Economies ed. Daniel Denison. }\end{array}$ & Marc Weinstein & March 1998 \\
\hline $\begin{array}{l}\text { No. 202: Corporate Transformation and } \\
\text { Organizational Learning: The People's } \\
\text { Republic of China. Forthcoming in Teaching } \\
\text { the Dinosaurs to Dance: Organizational } \\
\text { Change in Transition Economies ed. Daniel } \\
\text { Denison. }\end{array}$ & Meinolf Dierkes and Zhang Xinhua & March 1998 \\
\hline $\begin{array}{l}\text { No. 201: Foreign Direct Investment as a } \\
\text { Factor of Change: The Case of Slovakia. } \\
\text { Forthcoming in Teaching the Dinosaurs to } \\
\text { Dance: Organizational Change in Transition } \\
\text { Economies ed. Daniel Denison. }\end{array}$ & Sonia Ferencikova & February 1998 \\
\hline $\begin{array}{l}\text { No. 200: Radical versus Incremental Change: } \\
\text { The Role of Capabilities, Competition, and } \\
\text { Leaders. Forthcoming in Teaching the }\end{array}$ & Karen L. Newman & February 1998 \\
\hline
\end{tabular}

Working Papers are available at: www.wdi.bus.umich.edu 


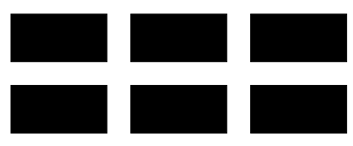

THE WILLIAM DAVIDSON INSTITUTE

AT THE UNIVERSITY OF MICHIGAN BUSINESSSCHOOL

\begin{tabular}{|c|c|c|}
\hline $\begin{array}{l}\text { Dinosaurs to Dance: Organizational Change in } \\
\text { Transition Economies ed. Daniel Denison. }\end{array}$ & & \\
\hline $\begin{array}{l}\text { No. 199: The Emergence of Market Practices } \\
\text { in China's Economic Transition: Price Setting } \\
\text { Practices in Shanghai's Industrial Firms. } \\
\text { Forthcoming in Teaching the Dinosaurs to } \\
\text { Dance: Organizational Change in Transition } \\
\text { Economies ed. Daniel Denison. }\end{array}$ & Douglas Guthrie & February 1998 \\
\hline $\begin{array}{l}\text { No. 198: The Application of Change } \\
\text { Management Methods at Business } \\
\text { Organizations Operating in Hungary: } \\
\text { Challenges in the Business and Cultural } \\
\text { Environment and First Practical Experiences. } \\
\text { Forthcoming in Teaching the Dinosaurs to } \\
\text { Dance: Organizational Change in Transition } \\
\text { Economies ed. Daniel Denison. }\end{array}$ & Dr. János Fehér & January 1998 \\
\hline $\begin{array}{l}\text { No. 197: Organizational Changes in Russian } \\
\text { Industrial Enterprises: Mutation of Decision- } \\
\text { Making Structures and Transformations of } \\
\text { Ownership. Forthcoming in Teaching the } \\
\text { Dinosaurs to Dance: Organizational Change in } \\
\text { Transition Economies ed. Daniel Denison. }\end{array}$ & Igor B. Gurkov & January 1998 \\
\hline $\begin{array}{l}\text { No. 196: Understanding and Managing } \\
\text { Challenges to the Romanian Companies } \\
\text { during Transition. Forthcoming in Teaching } \\
\text { the Dinosaurs to Dance: Organizational } \\
\text { Change in Transition Economies ed. Daniel } \\
\text { Denison. }\end{array}$ & Dan Candea and Rodica M. Candea & January 1998 \\
\hline $\begin{array}{l}\text { No. 195: Insider Lending and Economic } \\
\text { Transition: The Structure, Function, and } \\
\text { Performance Impact of Finance Companies in } \\
\text { Chinese Business Groups. Forthcoming in } \\
\text { Teaching the Dinosaurs to Dance: } \\
\text { Organizational Change in Transition } \\
\text { Economies ed. Daniel Denison. }\end{array}$ & Lisa A. Keister & December 1997 \\
\hline $\begin{array}{l}\text { No. 194: Japanese Investment in Transitional } \\
\text { Economies: Characteristics and Performance. } \\
\text { Forthcoming in Teaching the Dinosaurs to } \\
\text { Dance: Organizational Change in Transition } \\
\text { Economies ed. Daniel Denison. }\end{array}$ & Paul W. Beamish and Andrew Delios & November 1997 \\
\hline $\begin{array}{l}\text { No. 193: Building Successful Companies in } \\
\text { Transition Economies. Forthcoming in } \\
\text { Teaching the Dinosaurs to Dance: } \\
\text { Organizational Change in Transition } \\
\text { Economies ed. Daniel Denison. }\end{array}$ & Dr. Ivan Perlaki & January 1998 \\
\hline $\begin{array}{l}\text { No. 192: Russian Communitariansim: An } \\
\text { Invisible Fist in the Transformation Process of } \\
\text { Russia. Forthcoming in Teaching the } \\
\text { Dinosaurs to Dance: Organizational Change in } \\
\text { Transition Economies ed. Daniel Denison. }\end{array}$ & Charalambos Vlachoutsicos & July 1998 \\
\hline No. 191: Teaching the Dinosaurs to Dance & Michal Cakrt & September 1997 \\
\hline No. 190: Strategic Restructuring: Making & Lawrence P. King & September 1997 \\
\hline
\end{tabular}

Working Papers are available at: www.wdi.bus.umich.edu 


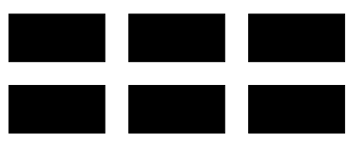

THE WILLIAM DAVIDSON INSTITUTE

AT THE UNIVERSITY OF MICHIGAN BUSINESSSCHOOL

\begin{tabular}{|c|c|c|}
\hline $\begin{array}{l}\text { Capitalism in Post-Communist Eastern } \\
\text { Europe. Forthcoming in Teaching the } \\
\text { Dinosaurs to Dance: Organizational Change in } \\
\text { Transition Economies ed. Daniel Denison. }\end{array}$ & & \\
\hline $\begin{array}{l}\text { No. 189: Published in: Regional Science and } \\
\text { Urban Economics, "Russia's Internal Border", } \\
29 \text { (5), September } 1999 .\end{array}$ & Daniel Berkowitz and David N. DeJong & July 1998 \\
\hline $\begin{array}{l}\text { No. 187: Corporate Structure and Performance } \\
\text { in Hungary }\end{array}$ & László Halpern and Gábor Kórsöi & July 1998 \\
\hline $\begin{array}{l}\text { No. 186: Performance of Czech Companies by } \\
\text { Ownership Structure }\end{array}$ & Andrew Weiss and Georgiy Nikitin & June 1998 \\
\hline $\begin{array}{l}\text { No. 185: Firm Performance in Bulgaria and } \\
\text { Estonia: The effects of competitive pressure, } \\
\text { financial pressure and disorganisation }\end{array}$ & Jozef Konings & July 1998 \\
\hline $\begin{array}{l}\text { No. 184: Investment and Wages during the } \\
\text { Transition: Evidence from Slovene Firms }\end{array}$ & Janez Prasnikar and Jan Svejnar & July 1998 \\
\hline $\begin{array}{l}\text { No. 183: Investment Portfolio under Soft } \\
\text { Budget: Implications for Growth, Volatility } \\
\text { and Savings }\end{array}$ & Chongen Bai and Yijiang Wang & July 1998 \\
\hline $\begin{array}{l}\text { No. 181: Delegation and Delay in Bank } \\
\text { Privatization }\end{array}$ & Loránd Ambrus-Lakatos and Ulrich Hege & July 1998 \\
\hline $\begin{array}{l}\text { No. 180: Financing Mechanisms and R\&D } \\
\text { Investment }\end{array}$ & Haizhou Huang and Chenggang $\mathrm{Xu}$ & July 1998 \\
\hline $\begin{array}{l}\text { No. 179: Organizational Culture and } \\
\text { Effectiveness: The Case of Foreign Firms in } \\
\text { Russia }\end{array}$ & Carl F. Fey and Daniel R. Denison & January 1999 \\
\hline $\begin{array}{l}\text { No. 178: Output and Unemployment } \\
\text { Dynamics in Transition }\end{array}$ & Vivek H. Dehejia and Douglas W. Dwyer & January 1998 \\
\hline $\begin{array}{l}\text { No. 177: Published in: Economics of } \\
\text { Transition,, "Bureaucracies in the Russian } \\
\text { Voucher Privatization" Vol. 8, No. 1, 2000, } \\
\text { pp. 37-57. }\end{array}$ & Guido Friebel & June 1998 \\
\hline $\begin{array}{l}\text { No. 176: Chronic Moderate Inflation in } \\
\text { Transition: The Tale of Hungary }\end{array}$ & János Vincze & June 1998 \\
\hline $\begin{array}{l}\text { No. 175: Privatisation and Market Structure in } \\
\text { a Transition Economy }\end{array}$ & John Bennett and James Maw & June 1998 \\
\hline $\begin{array}{l}\text { No. 174: Ownership and Managerial } \\
\text { Competition: Employee, Customer, or Outside } \\
\text { Ownership }\end{array}$ & Patrick Bolton and Chenggang $\mathrm{Xu}$ & June 1998 \\
\hline $\begin{array}{l}\text { No. 173: Intragovernment Procurement of } \\
\text { Local Public Good: A Theory of } \\
\text { Decentralization in Nondemocratic } \\
\text { Government }\end{array}$ & Chong-en Bai, Yu Pan and Yijiang Wang & June 1998 \\
\hline $\begin{array}{l}\text { No. 172: Political Instability and Growth in } \\
\text { Proprietary Economies }\end{array}$ & Jody Overland and Michael Spagat & August 1998 \\
\hline $\begin{array}{l}\text { No. 171: Published in Post-Communist } \\
\text { Economies, "Framework Issues in the } \\
\text { Privatization Strategies of the Czech Republic, } \\
\text { Hungary, and Poland" Vol. 11, no. } 1 \text { March } \\
\text { 1999. }\end{array}$ & Morris Bornstein & June 1998 \\
\hline $\begin{array}{l}\text { No. 170: Published in: European Journal of } \\
\text { Political Economy "Privatization, Ownership }\end{array}$ & Frantisek Turnovec & May 1998 \\
\hline
\end{tabular}

Working Papers are available at:

www.wdi.bus.umich.edu 


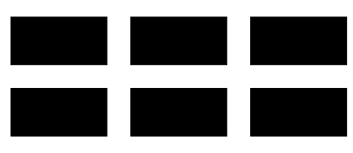

THE WILLIAM DAVIDSON INSTITUTE AT THE UNIVERSITY OF MICHIGAN BUSINESSSCHOOL

\begin{tabular}{|c|c|c|}
\hline $\begin{array}{l}\text { Structure and Transparency: How to Measure } \\
\text { a Real Involvement of the State" } 15(4), \\
\text { November } 1999, \text { pp. } 605-18 .\end{array}$ & & \\
\hline $\begin{array}{l}\text { No. } 169 \text { Published in: American Economic } \\
\text { Review, "Unemployment and the Social } \\
\text { Safety Net during Transitions to a Market } \\
\text { Economy: Evidence from Czech and Slovak } \\
\text { Men." Vol. 88, No. 5, Dec. 1998, pp. 1117- } \\
1142 \text {. }\end{array}$ & $\begin{array}{l}\text { John C. Ham, Jan Svejnar, and Katherine } \\
\text { Terrell }\end{array}$ & December 1998 \\
\hline $\begin{array}{l}\text { No. 167: Voucher Privatization with } \\
\text { Investment Funds: An Institutional Analysis }\end{array}$ & David Ellerman & March 1998 \\
\hline $\begin{array}{l}\text { No. 166: Published in: Marketing Issues in } \\
\text { Transitional Economies, "Value Priorities and } \\
\text { Consumer Behavior in a Transitional } \\
\text { Economy: The Case of South Africa" ed. } \\
\text { Rajeev Batra. }\end{array}$ & $\begin{array}{l}\text { Steven M. Burgess and Jan-Benedict E.M. } \\
\text { Steenkamp }\end{array}$ & August 1998 \\
\hline $\begin{array}{l}\text { No. 164: Finance and Investment in } \\
\text { Transition: Czech Enterprises, 1993-1994 }\end{array}$ & Ronald Anderson and Chantal Kegels & September 1997 \\
\hline $\begin{array}{l}\text { No. 163: European Union Trade and } \\
\text { Investment Flows U-Shaping Industrial } \\
\text { Output in Central and Eastern Europe: Theory } \\
\text { and Evidence }\end{array}$ & Alexander Repkine and Patrick P. Walsh & April 1998 \\
\hline $\begin{array}{l}\text { No. 162: Skill Acquisition and Private Firm } \\
\text { Creation in Transition Economies }\end{array}$ & Zuzana Brixiova and Wenli Li & October 1999 \\
\hline No. 161: Corruption in Transition & Susanto Basu and David D. Li & May 1998 \\
\hline $\begin{array}{l}\text { No. 160a: Tenures that Shook the World: } \\
\text { Worker Turnover in Russia, Poland and } \\
\text { Britain }\end{array}$ & $\begin{array}{l}\text { Hartmut Lehmann and Jonathan } \\
\text { Wadsworth }\end{array}$ & November 1999 \\
\hline $\begin{array}{l}\text { No. 160: Tenures that Shook the World: } \\
\text { Worker Turnover in the Russian Federation } \\
\text { and Poland }\end{array}$ & $\begin{array}{l}\text { Hartmut Lehmann and Jonathan } \\
\text { Wadsworth }\end{array}$ & June 1998 \\
\hline $\begin{array}{l}\text { No. 159: Does Market Structure Matter? New } \\
\text { Evidence from Russia }\end{array}$ & Annette N. Brown and J. David Brown & June 1998 \\
\hline $\begin{array}{l}\text { No. 158: Structural Adjustment and Regional } \\
\text { Long Term Unemployment in Poland }\end{array}$ & Hartmut Lehmann and Patrick P. Walsh & June 1997 \\
\hline $\begin{array}{l}\text { No. 157: Baby Boom or Bust? Changing } \\
\text { Fertility in Post-Communist Czech Republic } \\
\text { and Slovakia }\end{array}$ & Robert S. Chase & April 1998 \\
\hline $\begin{array}{l}\text { No. 156 Published in: Leadership and } \\
\text { Organization Development Journal, "Leading } \\
\text { Radical Change in Transition Economies." } \\
\text { Vol. 19, No. 6, 1998, pp. 309-324. }\end{array}$ & Karen L. Newman & June 1998 \\
\hline $\begin{array}{l}\text { No. } 155 \text { Published in: Oxford Review of } \\
\text { Economic Policy, "From Theory into } \\
\text { Practice? Restructuring and Dynamism in } \\
\text { Transition Economies." Vol. 13, No. 2, } \\
\text { Summer 1997, pp. 77-105. }\end{array}$ & Wendy Carlin and Michael Landesmann & June 1997 \\
\hline $\begin{array}{l}\text { No. 154: The Model and the Reality: } \\
\text { Assessment of Vietnamese SOE Reform- } \\
\text { Implementation at the Firm Level }\end{array}$ & $\begin{array}{l}\text { Edmund Malesky, Vu Thanh Hung, Vu } \\
\text { Thi Dieu Anh, and Nancy K. Napier }\end{array}$ & July 1998 \\
\hline $\begin{array}{l}\text { No. } 153 \text { Published in: Journal of Comparative } \\
\text { Economics, "Causes of the Soft Budget }\end{array}$ & David D. Li and Minsong Liang & March 1998 \\
\hline
\end{tabular}

Working Papers are available at: www.wdi.bus.umich.edu 


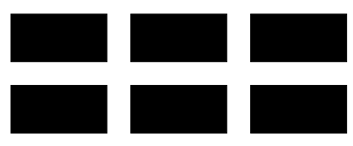

THE WILLIAM DAVIDSON INSTITUTE

AT THE UNIVERSITY OF MICHIGAN BUSINESSSCHOOL

\begin{tabular}{|c|c|c|}
\hline $\begin{array}{l}\text { Constraint: Evidence on Three Explanations." } \\
\text { Vol. 26, No. 1, March 1998, pp. 104-116. }\end{array}$ & & \\
\hline $\begin{array}{l}\text { No. } 152 \text { Published in: Comparative Economic } \\
\text { Studies, "Enterprise Restructuring in Russia's } \\
\text { Transition Economy: Formal and Informal } \\
\text { Mechanisms." Vol. 40, No. 2, Summer 1998, } \\
\text { pp. 5-52. }\end{array}$ & Susan J. Linz and Gary Krueger & April 1998 \\
\hline $\begin{array}{l}\text { No. 151: Labor Productivity in Transition: A } \\
\text { Regional Analysis of Russian Industry }\end{array}$ & Susan J. Linz & May 1998 \\
\hline $\begin{array}{l}\text { No. 150: Tax Avoidance and the Allocation of } \\
\text { Credit. Forthcoming in Financial Systems in } \\
\text { Transition: The Design of Financial Systems } \\
\text { in Central Europe eds. Anna Meyendorff and } \\
\text { Anjan Thakor. }\end{array}$ & Anna Meyendorff & June 1998 \\
\hline $\begin{array}{l}\text { No. 149: Commitment, Versatility and } \\
\text { Balance: Determinants of Work Time } \\
\text { Standards and Norms in a Multi-Country } \\
\text { Study of Software Engineers }\end{array}$ & Leslie Perlow and Ron Fortgang & April 1998 \\
\hline $\begin{array}{l}\text { No. 148: Changes in Poland's Transfer } \\
\text { Payments in the 1990s: the Fate of Pensioners }\end{array}$ & Bozena Leven & June 1998 \\
\hline $\begin{array}{l}\text { No. 147: Environmental Protection and } \\
\text { Economic Development: The Case of the } \\
\text { Huaihe River Basin Cleanup Plan }\end{array}$ & $\begin{array}{l}\text { Robert Letovsky, Reze Ramazani, and } \\
\text { Debra Murphy }\end{array}$ & June 1998 \\
\hline $\begin{array}{l}\text { No. 146: Chief Executive Compensation } \\
\text { During Early Transition: Further Evidence } \\
\text { from Bulgaria }\end{array}$ & $\begin{array}{l}\text { Derek C. Jones, Takao Kato, and Jeffrey } \\
\text { Miller }\end{array}$ & June 1998 \\
\hline $\begin{array}{l}\text { No. } 145 \text { Published in: Economics of } \\
\text { Transition, "Women's Unemployment During } \\
\text { the Transition: Evidence from Czech and } \\
\text { Slovak Micro Data," Vol. 7, No. 1, May 1999, } \\
\text { pp. 47-78. }\end{array}$ & $\begin{array}{l}\text { John Ham, Jan Svejnar, and Katherine } \\
\text { Terrell }\end{array}$ & May 1998 \\
\hline No. 144: Investment and Wages in Slovenia & Janez Prasnikar & May 1998 \\
\hline $\begin{array}{l}\text { No. } 143 \text { Published in: Review of Financial } \\
\text { Studies, "Optimal Bankruptcy Laws Across } \\
\text { Different Economic Systems," 12(2), Summer } \\
\text { 1999, pgs. 347-77. }\end{array}$ & Elazar Berkovitch and Ronen Israel & March 1998 \\
\hline $\begin{array}{l}\text { No. 142: Industrial Policy and Poverty in } \\
\text { Transition Economies: Two Steps Forward or } \\
\text { One Step Back? }\end{array}$ & Susan J. Linz & March 1998 \\
\hline $\begin{array}{l}\text { No. 141: Collective Ownership and } \\
\text { Privatization of China's Village Enterprises }\end{array}$ & Suwen Pan and Albert Park & April 1998 \\
\hline $\begin{array}{l}\text { No. 140: A Comparative Look at Labor } \\
\text { Mobility in the Czech Republic: Where have } \\
\text { all the Workers Gone? }\end{array}$ & Vit Sorm and Katherine Terrell & April 1999 \\
\hline $\begin{array}{l}\text { No. 139: The Failure of the Government-Led } \\
\text { Program of Corporate Reorganization in } \\
\text { Romania }\end{array}$ & Simeon Djankov and Kosali Ilayperuma & September 1997 \\
\hline $\begin{array}{l}\text { No. 138: Ownership and Employment in } \\
\text { Russian Industry: 1992-1995 }\end{array}$ & Susan J. Linz & March 1998 \\
\hline $\begin{array}{l}\text { No. } 137 \text { Published in: Journal of Political } \\
\text { Economy, "Reform Without Losers: An } \\
\text { Interpretation of China's Dual-Track }\end{array}$ & $\begin{array}{l}\text { Lawrence J. Lau, Yingyi Qian, and Gerard } \\
\text { Roland }\end{array}$ & November 1997 \\
\hline
\end{tabular}

Working Papers are available at: www.wdi.bus.umich.edu 


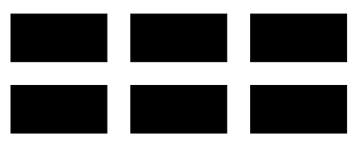

THE WILLIAM DAVIDSON INSTITUTE

AT THE UNIVERSITY OF MICHIGAN BUSINESSSCHOOL

\begin{tabular}{|c|c|c|}
\hline $\begin{array}{l}\text { Approach to Transition," Feb. 2000; Vol. 108, } \\
\text { Iss. } 1 ; \text { pg. } 120\end{array}$ & & \\
\hline $\begin{array}{l}\text { No. } 136 \text { Published in: European Economic } \\
\text { Review, "The Political Economy of Mass } \\
\text { Privatization and the Risk of Expropriation," } \\
\text { 44(2), February 2000, pgs. } 393-421\end{array}$ & Klaus M. Schmidt & March 1998 \\
\hline $\begin{array}{l}\text { No. 135: Radical Organizational Change: The } \\
\text { Role of Starting Conditions, Competition, and } \\
\text { Leaders }\end{array}$ & Karen L. Newman & January 1998 \\
\hline $\begin{array}{l}\text { No. 134: To Restructure or Not to Restructure: } \\
\text { Informal Activities and Enterprise Behavior in } \\
\text { Transition }\end{array}$ & Clifford Gaddy and Barry W. Ickes & May 1998 \\
\hline $\begin{array}{l}\text { No. 133: Management 101: Behavior of Firms } \\
\text { in Transition Economies }\end{array}$ & Josef C. Brada & March 1998 \\
\hline $\begin{array}{l}\text { No. } 132 \text { Published in: Quarterly Journal of } \\
\text { Economics, "Interfirm Relationships and } \\
\text { Informal Credit in Vietnam," 114(4), Nov. } \\
\text { 1999, pgs. 1285-1320 }\end{array}$ & John McMillan and Christopher Woodruff & February 1998 \\
\hline $\begin{array}{l}\text { No. } 131 \text { Published in: Comparative Economic } \\
\text { Studies, "Will Restructuring Hungarian } \\
\text { Companies Innovate? An Investigation Based } \\
\text { on Joseph Berliner's Analysis of Innovation in } \\
\text { Soviet Industry." Vol. 40, No. 2, Summer } \\
\text { 1998, pp. 53-74. }\end{array}$ & John B. Bonin and Istvan Abel & March 1998 \\
\hline $\begin{array}{l}\text { No. 130: Published in The American } \\
\text { Economic Review, "Changing Incentives of } \\
\text { the Chinese Bureaucracy." May, } 1998 .\end{array}$ & David D. Li & January 1998 \\
\hline $\begin{array}{l}\text { No. 129: Restructuring Investment in } \\
\text { Transition: A Model of the Enterprise } \\
\text { Decision }\end{array}$ & Richard E. Ericson & January 1998 \\
\hline $\begin{array}{l}\text { No. } 128 \text { Published in: Comparative Economic } \\
\text { Studies, "Job Rights in Russian Firms: } \\
\text { Endangered or Extinct Institutions?" Vol. 40, } \\
\text { No. 4, Winter 1998, pp. 1-32. }\end{array}$ & Susan J. Linz & January 1998 \\
\hline $\begin{array}{l}\text { No. 127: Accounting for Growth in Post- } \\
\text { Soviet Russia }\end{array}$ & Daniel Berkowitz and David N. DeJong & January 1998 \\
\hline $\begin{array}{l}\text { No. } 126 \text { Published in: Economics of } \\
\text { Transition, "From Federalism, Chinese Style, } \\
\text { to Privatization Chinese Style," 7(1), 1999, } \\
\text { pgs. 103-31 }\end{array}$ & $\begin{array}{l}\text { Yuanzheng Cao, Yingyi Qian, and Barry } \\
\text { R. Weingast }\end{array}$ & December 1997 \\
\hline $\begin{array}{l}\text { No. 125: Market Discipline in Conglomerate } \\
\text { Banks: Is an Internal Allocation of Cost of } \\
\text { Capital Necessary as Incentive Device? } \\
\text { Forthcoming in Financial Systems in } \\
\text { Transition: The Design of Financial Systems } \\
\text { in Central Europe eds. Anna Meyendorff and } \\
\text { Anjan Thakor. }\end{array}$ & Arnoud W. A. Boot and Anjolein Schmeits & November 1997 \\
\hline $\begin{array}{l}\text { No. 124: Financial Discipline in the Enterprise } \\
\text { Sector in Transition Countries: How Does } \\
\text { China Compare? }\end{array}$ & Shumei Gao and Mark E. Schaffer & February 1998 \\
\hline $\begin{array}{l}\text { No. 123: Considerations of an Emerging } \\
\text { Marketplace: Managers' Perceptions in the }\end{array}$ & Brent Chrite and David Hudson & February 1998 \\
\hline
\end{tabular}

Working Papers are available at: www.wdi.bus.umich.edu 


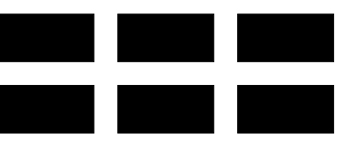

THE WILLIAM DAVIDSON INSTITUTE AT THE UNIVERSITY OF MICHIGAN BUSINESSSCHOOL

\begin{tabular}{|c|c|c|}
\hline Southern African Economic Community & & \\
\hline $\begin{array}{l}\text { No. 122: A Model of the Informal Economy in } \\
\text { Transition Economies }\end{array}$ & $\begin{array}{l}\text { Simon Commander and Andrei } \\
\text { Tolstopiatenko }\end{array}$ & November 1997 \\
\hline $\begin{array}{l}\text { No. 121: Local Labour Market Dynamics in } \\
\text { the Czech and Slovak Republics }\end{array}$ & Peter Huber and Andreas Worgotter & November 1997 \\
\hline $\begin{array}{l}\text { No. 119: Institutional Upheaval and Company } \\
\text { Transformation in Emerging Market } \\
\text { Economies }\end{array}$ & Karen L. Newman & March 1998 \\
\hline $\begin{array}{l}\text { No. 118: Industrial Decline and Labor } \\
\text { Reallocation in Romania }\end{array}$ & John S. Earle & October 1997 \\
\hline $\begin{array}{l}\text { No. 117: Notes for an Essay on the Soft } \\
\text { Budget Constraint }\end{array}$ & Lorand Ambrus-Lakatos & January 1997 \\
\hline $\begin{array}{l}\text { No. 116: Labor Demand During Transition in } \\
\text { Hungary }\end{array}$ & Gabor Korosi & October 1997 \\
\hline $\begin{array}{l}\text { No. 115: Enterprise Performance and } \\
\text { Managers' Profiles }\end{array}$ & Simeon Djankov and Stijn Claessens & December 1997 \\
\hline $\begin{array}{l}\text { No. 114b Employment and Wages in } \\
\text { Enterprises under Communism and in } \\
\text { Transition: Evidence From Central Europe and } \\
\text { Russia }\end{array}$ & Swati Basu, Saul Estrin, and Jan Svejnar & April 2000 \\
\hline $\begin{array}{l}\text { No. 114: Employment and Wage Behavior of } \\
\text { Enterprises in Transitional Economies }\end{array}$ & Swati Basu, Saul Estrin, and Jan Svejnar & October 1997 \\
\hline $\begin{array}{l}\text { No. 113: Preliminary Evidence on Active } \\
\text { Labor Programs' Impact in Hungary and } \\
\text { Poland }\end{array}$ & Christopher J. O’Leary & October 1997 \\
\hline $\begin{array}{l}\text { No. 111: Unemployment Benefits and } \\
\text { Incentives in Hungary: New Evidence }\end{array}$ & Joachim Wolff & October 1997 \\
\hline $\begin{array}{l}\text { No. 110: Published in: Empirical Economics, } \\
\text { "Long-Term Unemployment, Unemployment } \\
\text { Benefits and Social Assistance: The Polish } \\
\text { Experience" Empirical-Economics; 23(1-2), } \\
\text { 1998, pages 55-85. }\end{array}$ & Marek Gora and Christoph M. Schmidt & April 1997 \\
\hline $\begin{array}{l}\text { No. } 109 \text { Published in: Industrial and Labor } \\
\text { Relations Review, "Markets for Communist } \\
\text { Human Capital: Returns to Education and } \\
\text { Experience in Post-Communist Czech } \\
\text { Republic and Slovakia." Vol. 51, No. 3, April } \\
\text { 1998, pp. 401-423. }\end{array}$ & Robert S. Chase & October 1997 \\
\hline $\begin{array}{l}\text { No. 107: The Worker-Firm Matching in the } \\
\text { Transition: (Why) Are the Czechs More } \\
\text { Successful Than Others? }\end{array}$ & $\begin{array}{l}\text { Daniel Münich, Jan Svejnar, and Katherine } \\
\text { Terrell }\end{array}$ & October 1997 \\
\hline $\begin{array}{l}\text { No. } 106 \text { Published in: Journal of Comparative } \\
\text { Economics, "Job Creation, Job Destruction } \\
\text { and Growth of Newly Established, Privatized } \\
\text { and State-Owned Enterprises in Transition } \\
\text { Economies: Survey Evidence from Bulgaria, } \\
\text { Hungary, and Romania," Vol. 26, No.3, } \\
\text { September 1998, pp. 429-445. }\end{array}$ & Valentijn Bilsen and Jozef Konings & September 1998 \\
\hline $\begin{array}{l}\text { No. 105: Getting Behind the East-West } \\
\text { [German] Wage Differential: Theory and } \\
\text { Evidence }\end{array}$ & Michael Burda and Christoph Schmidt & May 1997 \\
\hline No. 104: The Birth of the "Wage Curve" in & Gabor Kertesi and Janos Kollo & October 1997 \\
\hline
\end{tabular}

Working Papers are available at:

www.wdi.bus.umich.edu 


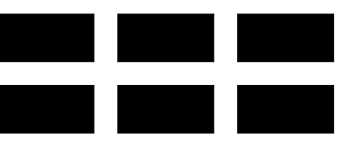

THE WILLIAM DAVIDSON INSTITUTE AT THE UNIVERSITY OF MICHIGAN BUSINESSSCHOOL

\begin{tabular}{|c|c|c|}
\hline Hungary, 1989-95 & & \\
\hline $\begin{array}{l}\text { No. 103: Published in: Journal of Comparative } \\
\text { Economics, "Grime and Punishment: Job } \\
\text { Insecurity and Wage Arrears in the Russian } \\
\text { Federation" 27, 595-617 (1999). }\end{array}$ & $\begin{array}{l}\text { Hartmut Lehmann, Jonathan Wadsworth, } \\
\text { and Alessandro Acquisti }\end{array}$ & October 1997 \\
\hline No. 102: Social Networks in Transition & $\begin{array}{l}\text { Lorena Barberia, Simon Johnson, and } \\
\text { Daniel Kaufmann }\end{array}$ & October 1997 \\
\hline $\begin{array}{l}\text { No. 101: Depreciation and Russian Corporate } \\
\text { Finance: A Pragmatic Approach to Surviving } \\
\text { the Transition }\end{array}$ & Susan J. Linz & November 1997 \\
\hline No. 100: Romanian Financial System Reform & Anna Meyendorff and Anjan V. Thakor & November 1997 \\
\hline $\begin{array}{l}\text { No. 99: Proceedings of the Conference on } \\
\text { Strategic Alliances in Transitional Economies, } \\
\text { held May 20, } 1997 \text { at the Davidson Institute }\end{array}$ & Edited by Cynthia Koch & May 1997 \\
\hline $\begin{array}{l}\text { No. 98: Institutions, Strain and the } \\
\text { Underground Economy }\end{array}$ & Daniel Daianu and Lucian Albu & November 1997 \\
\hline $\begin{array}{l}\text { No. 97: Structure and Strain in Explaining } \\
\text { Inter-Enterprise Arrears }\end{array}$ & Daniel Daianu & November 1997 \\
\hline $\begin{array}{l}\text { No. 96: Resource Misallocation and Strain: } \\
\text { Explaining Shocks in Post-Command } \\
\text { Economies }\end{array}$ & Daniel Daianu & November 1997 \\
\hline $\begin{array}{l}\text { No. 95: Published in: Finance-a-Uver, "Czech } \\
\text { Money Market: Emerging Links Among } \\
\text { Interest Rates." 48(2) } 1998 \text { pp. 99-109. }\end{array}$ & Jan Hanousek and Evzen Kocenda & November 1997 \\
\hline $\begin{array}{l}\text { No. 94: Pre-Reform Industry and the } \\
\text { State Monopsony in China }\end{array}$ & Xiao-Yuan Dong and Louis Putterman & October 1997 \\
\hline $\begin{array}{l}\text { No. 93: China's State-Owned Enterprises } \\
\text { In the First Reform Decade: } \\
\text { An Analysis of a Declining Monopsony }\end{array}$ & Xiao-Yuan Dong and Louis Putterman & October 1997 \\
\hline $\begin{array}{l}\text { No. 92: Expatriate Management in the Czech } \\
\text { Republic }\end{array}$ & Richard B. Peterson & September 1997 \\
\hline $\begin{array}{l}\text { No. 91: China and the Idea of Economic } \\
\text { Reform }\end{array}$ & Thomas G. Rawski & April 1997 \\
\hline $\begin{array}{l}\text { No. } 90 \text { Published in: China Economic Review, } \\
\text { "China's State Enterprise Reform: An } \\
\text { Overseas Perspective." Vol. 8, Spring 1997, } \\
\text { pp. 89-98. }\end{array}$ & Thomas G. Rawski & July 1997 \\
\hline $\begin{array}{l}\text { No. 89: The Economic Determinants of } \\
\text { Internal Migration Flows in Russia During } \\
\text { Transition }\end{array}$ & Annette N. Brown & July 1997 \\
\hline $\begin{array}{l}\text { No. 88: Gender Wage Gaps in China's Labor } \\
\text { Market: Size, Structure, Trends }\end{array}$ & $\begin{array}{l}\text { Margaret Maurer-Fazio, Thomas G. } \\
\text { Rawski, and Wei Zhang }\end{array}$ & July 1997 \\
\hline $\begin{array}{l}\text { No. 87: Privatisation in Central and Eastern } \\
\text { Europe }\end{array}$ & Saul Estrin & June 1997 \\
\hline $\begin{array}{l}\text { No. 86: Published in : Economics of } \\
\text { Transition, "The Effect of Privatization on } \\
\text { Wealth Distribution in Russia." v. 7, no. 2, } \\
\text { 1999, pp. 449-65 }\end{array}$ & Michael Alexeev & February 1998 \\
\hline $\begin{array}{l}\text { No. 85: Was Privatization in Eastern Germany } \\
\text { a Special Case? Some Lessons from the } \\
\text { Treuhand }\end{array}$ & Uwe Siegmund & September 1997 \\
\hline No. 84: Start-ups and Transition & Daniel M. Berkowitz and David J. Cooper & September 1997 \\
\hline
\end{tabular}

Working Papers are available at: www.wdi.bus.umich.edu 


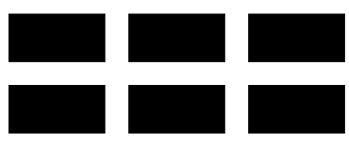

ThE WiLliam DAVIDSON InSTITUTE AT THE UNIVERSITY OF MICHIGAN BUSINESSSCHOOL

\begin{tabular}{|c|c|c|}
\hline $\begin{array}{l}\text { No. 83: Which Enterprises (Believe They) } \\
\text { Have Soft Budgets after Mass Privatization? } \\
\text { Evidence from Mongolia }\end{array}$ & $\begin{array}{l}\text { James Anderson, Georges Korsun, and } \\
\text { Peter Murrell }\end{array}$ & October 1997 \\
\hline $\begin{array}{l}\text { No. 82: Published in: European Economic } \\
\text { Review, "Unemployment Dynamics and the } \\
\text { Restructuring of the Slovak Unemployment } \\
\text { Benefit System." April, } 1997 .\end{array}$ & Martina Lubyova and Jan C. van Ours & June 1997 \\
\hline $\begin{array}{l}\text { No. 81: Determinants of Unemployment } \\
\text { Duration in Russia }\end{array}$ & Mark C. Foley & August 1997 \\
\hline $\begin{array}{l}\text { No. 80: The Many Faces of Information } \\
\text { Disclosure }\end{array}$ & Arnoud W.A. Boot and Anjan V. Thakor & October 1997 \\
\hline $\begin{array}{l}\text { No. 79: Published in: Journal of Finance, } \\
\text { "Foreign Speculators and Emerging Equity } \\
\text { Markets."v.22, iss. 2, 2000, pp. 565-613 }\end{array}$ & Geert Bekaert and Campbell R. Harvey & August 1997 \\
\hline $\begin{array}{l}\text { No. 78: The Relationship Between Economic } \\
\text { Factors and Equity Markets in Central Europe }\end{array}$ & Jan Hanousek and Randall K. Filer & June 1997 \\
\hline $\begin{array}{l}\text { No. } 77 \text { Published in: Economics of Transition, } \\
\text { "A Gini Decomposition Analysis of Inequality } \\
\text { in the Czech and Slovak Republics During the } \\
\text { Transition," Vol. 6, No.1, May 1998, pp. 23- } \\
\text { 46. }\end{array}$ & Thesia I. Garner and Katherine Terrell & May 1998 \\
\hline $\begin{array}{l}\text { No. 76: China's Emerging Market for Property } \\
\text { Rights: Theoretical and Empirical } \\
\text { Perspectives }\end{array}$ & Gary H. Jefferson and Thomas G. Rawski & June 1997 \\
\hline $\begin{array}{l}\text { No. 75b: Test of Permanent Income } \\
\text { Hypothesis on Czech Voucher Privatization }\end{array}$ & Jan Hanousek and Zdenek Tima & October 1997 \\
\hline $\begin{array}{l}\text { No. 74: Determinants of Performance of } \\
\text { Manufacturing Firms in Seven European } \\
\text { Transition Economies }\end{array}$ & $\begin{array}{l}\text { Stijn Claessens, Simeon Djankov, and } \\
\text { Gerhard Pohl }\end{array}$ & February 1997 \\
\hline $\begin{array}{l}\text { No. } 73 \text { Published in: Economics of Transition, } \\
\text { "The Restructuring of Large Firms in Slovak } \\
\text { Republic." Vol. 6, No. 1, May 1998, pp. 67- } \\
85\end{array}$ & Simeon Djankov and Gerhard Pohl & May 1998 \\
\hline $\begin{array}{l}\text { No. 72: Law, Relationships, and Private } \\
\text { Enforcement: Transactional Strategies of } \\
\text { Russian Enterprises }\end{array}$ & $\begin{array}{l}\text { Kathryn Hendley, Peter Murrell, and Randi } \\
\text { Ryterman }\end{array}$ & November 1998 \\
\hline $\begin{array}{l}\text { No. 71: Giving Credit Where Credit Is Due: } \\
\text { The Changing Role of Rural Financial } \\
\text { Institutions in China }\end{array}$ & Albert Park, Loren Brandt, and John Giles & March 1997 \\
\hline $\begin{array}{l}\text { No. 70: Privatization Versus Competition: } \\
\text { Changing Enterprise Behavior in Russia }\end{array}$ & John S. Earle and Saul Estrin & Spring 1997 \\
\hline $\begin{array}{l}\text { No. 69: Russian Managers under Storm: } \\
\text { Explicit Reality and Implicit Leadership } \\
\text { Theories (A Pilot Exploration) }\end{array}$ & Igor Gurkov & October 1998 \\
\hline $\begin{array}{l}\text { No. 68: The Political Economy of Central- } \\
\text { Local Relations in China: Inflation and } \\
\text { Investment Controls During the Reform Era }\end{array}$ & Yasheng Huang & Spring 1997 \\
\hline $\begin{array}{l}\text { No. 67: Between Two Coordination Failures: } \\
\text { Automotive Industrial Policy in China with a } \\
\text { Comparison to Korea }\end{array}$ & Yasheng Huang & Spring 1997 \\
\hline $\begin{array}{l}\text { No. } 66 \text { Published in: Post-Soviet Geography } \\
\text { and Economics, "Red Executives in Russia's }\end{array}$ & Susan J. Linz & January 1997 \\
\hline
\end{tabular}

Working Papers are available at: www.wdi.bus.umich.edu 


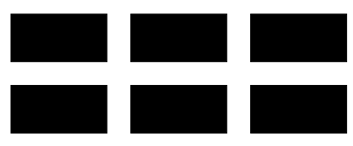

THE WILLIAM DAVIDSON INSTITUTE AT THE UNIVERSITY OF MICHIGAN BUSINESSSCHOOL

\begin{tabular}{|c|c|c|}
\hline $\begin{array}{l}\text { Transition Economy." Vol. 27, No. 10, } \\
\text { November 1996, pp. 633-651. }\end{array}$ & & \\
\hline $\begin{array}{l}\text { No. } 65 \text { Published in: Industrial and Corporate } \\
\text { Change, "On the Sequencing of Privatization } \\
\text { in Transition Economies." Vol. 7, No. 1, } \\
1998 .\end{array}$ & Gautam Ahuja and Sumit K. Majumdar & April 1997 \\
\hline $\begin{array}{l}\text { No. 64: Published in: Journal of Law and } \\
\text { Economics, "Foreign Ownership and } \\
\text { Profitability: Property Rights, Control and the } \\
\text { Performance of Firms in Indian Industry" } \\
\text { 42(1), April 1999, pp. 209-38. }\end{array}$ & $\begin{array}{l}\text { Pradeep K. Chhibber and Sumit K. } \\
\text { Majumdar }\end{array}$ & April 1997 \\
\hline $\begin{array}{l}\text { No. 63: How Taxing Is Corruption on } \\
\text { International Investors? }\end{array}$ & Shang-Jin Wei & February 1997 \\
\hline $\begin{array}{l}\text { No. 62: What Can We Learn from the } \\
\text { Experience of Transitional Economies with } \\
\text { Labour Market Policies? }\end{array}$ & Tito Boeri & 1997 \\
\hline $\begin{array}{l}\text { No. 61: Published in: Accounting } \\
\text { Organizations and Society, "Economic } \\
\text { Transition, Strategy and the Evolution of } \\
\text { Management Accounting Practices: The Case } \\
\text { of India" 24(5,6), Jul/Aug 1999, pp. 379-412. }\end{array}$ & $\begin{array}{l}\text { Shannon W. Anderson and William N. } \\
\text { Lanen }\end{array}$ & April 1997 \\
\hline $\begin{array}{l}\text { No. 60a: Enterprise Investment During the } \\
\text { Transition: Evidence from Czech Panel Data }\end{array}$ & Lubomír Lizal and Jan Svejnar & December 1997 \\
\hline $\begin{array}{l}\text { No. 59: Published in: Journal of Law, } \\
\text { Economics, and Organization, "Institutional } \\
\text { Environment, Community Government, and } \\
\text { Corporate Governance: Understanding } \\
\text { China's Township-Village Enterprises." 14(1), } \\
\text { April 1998, pages 1-23 }\end{array}$ & Jiahua Che and Yingyi Qian & April 1997 \\
\hline $\begin{array}{l}\text { No. 58: From the Grabbing Hand to the } \\
\text { Helping Hand }\end{array}$ & Jiahua Che & June 2000 \\
\hline $\begin{array}{l}\text { No. 57: Published in: Brookings Papers on } \\
\text { Economic Activity, "The Unofficial Economy } \\
\text { in Transition." 1: } 1998 \text {. }\end{array}$ & $\begin{array}{l}\text { Simon Johnson, Daniel Kaufmann, and } \\
\text { Andrei Schleifer }\end{array}$ & June 1997 \\
\hline $\begin{array}{l}\text { No. 56: Taxes and Government Incentives: } \\
\text { Eastern Europe vs. China }\end{array}$ & Roger H. Gordon and David D. Li & April 1997 \\
\hline No. 55: Corruption and Reform & Susanto Basu and David Li & June 1996 \\
\hline $\begin{array}{l}\text { No. 54: Decentralization and the } \\
\text { Macroeconomic Consequences of } \\
\text { Commitment to State-Owned Firms }\end{array}$ & Loren Brandt and Xiaodong Zhu & June 1997 \\
\hline $\begin{array}{l}\text { No. 53: Published in: The International } \\
\text { Journal of Industrial Organization, } \\
\text { "Competitive Shocks and Industrial Structure: } \\
\text { The Case of Polish Manufacturing." August, } \\
\text { 1999. . }\end{array}$ & Pankaj Ghemawat and Robert E. Kennedy & May 1997 \\
\hline $\begin{array}{l}\text { No. 52: Published in: The Quarterly Journal of } \\
\text { Economics, "Insecure Property Rights and } \\
\text { Government Ownership of Firms." May, } \\
1998 .\end{array}$ & Jiahua Che and Yingyi Qian & May 1997 \\
\hline $\begin{array}{l}\text { No. 51: Incentives, Scale Economies, and } \\
\text { Organizational Form }\end{array}$ & $\begin{array}{l}\text { Eric Maskin, Yingyi Qian, and Chenggang } \\
\mathrm{Xu}\end{array}$ & May 1997 \\
\hline No. 50: Published in: Post-Soviet-Affairs, & Barry W. Ickes, Peter Murrell, and Randi & March 1997 \\
\hline
\end{tabular}

Working Papers are available at: www.wdi.bus.umich.edu 


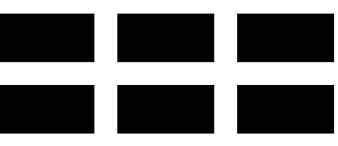

THE WILLIAM DAVIDSON INSTITUTE AT THE UNIVERSITY OF MICHIGAN BUSINESSSCHOOL

\begin{tabular}{|c|c|c|}
\hline $\begin{array}{l}\text { "End of the Tunnel? The Effects of Financial } \\
\text { Stabilization in Russia" April-June 1997, } \\
\text { pages 105-33 }\end{array}$ & Ryterman & \\
\hline $\begin{array}{l}\text { No. 49: The Evolution of Bank Credit Quality } \\
\text { in Transition: Theory and Evidence from } \\
\text { Romania }\end{array}$ & Enrico C. Perotti and Octavian Carare & October 1996 \\
\hline $\begin{array}{l}\text { No. 48: Where Do the Leaders Trade? } \\
\text { Information Revelation and Interactions } \\
\text { Between the Segments of Czech Capital } \\
\text { Markets }\end{array}$ & Jan Hanousek and Libor Nemecek & May 1997 \\
\hline $\begin{array}{l}\text { No. 47: Firms' Heterogeneity in Transition: } \\
\text { Evidence from a Polish Panel Data Set }\end{array}$ & Irena Grosfeld and Jean-François Nivet & May 1997 \\
\hline $\begin{array}{l}\text { No. 46: Strategic Creditor Passivity, } \\
\text { Regulation, and Bank Bailouts }\end{array}$ & Janet Mitchell & May 1997 \\
\hline $\begin{array}{l}\text { No. 45a: Published in: Journal of Public } \\
\text { Economics, "Tax Rights in Transition } \\
\text { Economies: A Tragedy of the Commons." } 76 \text {, } \\
\text { 2000, pp. 369-397 }\end{array}$ & Daniel M. Berkowitz and Wei Li & September 1997 \\
\hline $\begin{array}{l}\text { No. 44a: The Information Content of Stock } \\
\text { Markets: Why do Emerging Markets have } \\
\text { Synchronous Stock Price Movements? } \\
\text { (forthcoming in the Journal of Financial } \\
\text { Economics). }\end{array}$ & $\begin{array}{l}\text { Randall Morck, Bernard Yeung, and } \\
\text { Wayne Yu }\end{array}$ & February 1999 \\
\hline $\begin{array}{l}\text { No. 43: Agency in Project Screening and } \\
\text { Termination Decisions: Why Is Good Money } \\
\text { Thrown After Bad? }\end{array}$ & Chong-en Bai and Yijiang Wang & May 1997 \\
\hline $\begin{array}{l}\text { No. 42: Published in: Economics of } \\
\text { Transition, "Channels of Redistribution: } \\
\text { Inequality and Poverty in the Russian } \\
\text { Transition." Vol. } 7 \text { (2) } 1999 .\end{array}$ & $\begin{array}{l}\text { Simon Commander, Andrei } \\
\text { Tolstopiatenko, and Ruslan Yemtsov }\end{array}$ & May 1997 \\
\hline $\begin{array}{l}\text { No. 41: Published in: Economics of } \\
\text { Transition, "Labour Market Characteristics } \\
\text { and Profitability: Econometric Analysis of } \\
\text { Hungarian Exporting Firms, 1986-1995" 6(1), } \\
\text { May 1998, pages 145-62 }\end{array}$ & László Halpern and Gabor Korosi & May 1997 \\
\hline $\begin{array}{l}\text { No. 40: Published in: the Harvard Law } \\
\text { Review, "The Tragedy of the Anticommons: } \\
\text { Property in the Transition from Marx to } \\
\text { Markets." January } 1998 \text {. }\end{array}$ & Michael Heller & February 1997 \\
\hline $\begin{array}{l}\text { No. 39: Privatization and Managerial } \\
\text { Efficiency }\end{array}$ & Olivier Debande and Guido Friebel & May 1997 \\
\hline $\begin{array}{l}\text { No. } 38 \text { Published in: The Quarterly Journal of } \\
\text { Economics, "Disorganization." Vol. 112, No. } \\
\text { 4, November 1997, pp. 1091-1126. }\end{array}$ & Olivier Blanchard and Michael Kremer & January 1997 \\
\hline $\begin{array}{l}\text { No. 37: Published in: Economics of } \\
\text { Transition, "Transition and the Output Fall." } \\
7(1), 1999 \text {, pages 1-28. }\end{array}$ & Gérard Roland and Thierry Verdier & March 1997 \\
\hline $\begin{array}{l}\text { No. 36: Restructuring an Industry During } \\
\text { Transition: A Two-Period Model }\end{array}$ & Richard Ericson & September 1996 \\
\hline $\begin{array}{l}\text { No. 34: The East-West Joint Venture: BC } \\
\text { Torsion Case Study }\end{array}$ & Sonia Ferencikova and Vern Terpstra & December 1998 \\
\hline No. 33 Published in: Journal of Comparative & Daniel Berkowitz, David DeJong, and & December 1998 \\
\hline
\end{tabular}

Working Papers are available at:

www.wdi.bus.umich.edu 


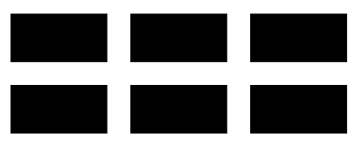

THE WILLIAM DAVIDSON INSTITUTE AT THE UNIVERSITY OF MICHIGAN BUSINESSSCHOOL

\begin{tabular}{|c|c|c|}
\hline $\begin{array}{l}\text { Economics, "Quantifying Price Liberalization } \\
\text { in Russia." Vol. 26, No. 4, December 1998, } \\
\text { pp. } 735-737 \text {. }\end{array}$ & Steven Husted & \\
\hline $\begin{array}{l}\text { No. 32: What Can North Korea Learn from } \\
\text { China's Market Reforms? }\end{array}$ & John McMillan & September 1996 \\
\hline $\begin{array}{l}\text { No. 31: Published in : China-Economic- } \\
\text { Review, "Towards a Model of China as a } \\
\text { Partially Reformed Developing Economy } \\
\text { Under a Semifederalist Government.", 9(1), } \\
\text { Spring 1998, pages 1-23. }\end{array}$ & Yijiang Wang and Chun Chang & March 1997 \\
\hline $\begin{array}{l}\text { No. 30: Convergence in Output in Transition } \\
\text { Economies: Central and Eastern Europe, } \\
\text { 1970-1995 }\end{array}$ & Saul Estrin and Giovanni Urga & February 1997 \\
\hline $\begin{array}{l}\text { No. 29: Published in: Economics of } \\
\text { Transition, "Altered Band and Exchange } \\
\text { Volatility." Volume 6, no. 1, 1998, 173-181. }\end{array}$ & Evzen Kocenda & March 1997 \\
\hline $\begin{array}{l}\text { No. 28: Published in: Quarterly Journal of } \\
\text { Economics, "Public Versus Private Ownership } \\
\text { of Firms: Evidence from Rural China." } \\
\text { Volume 113, no. 3, August 1998, 773-808. }\end{array}$ & Hehui Jin and Yingyi Qian & January 1997 \\
\hline $\begin{array}{l}\text { No. 27: East-West Joint Ventures in a } \\
\text { Transitional Economy: The Case of Slovakia }\end{array}$ & Sonia Ferencikova & March 1997 \\
\hline $\begin{array}{l}\text { No. 26: Published in Economic Analysis } \\
\text { "Behavior of a Slovenian Firm in Transition" } \\
\text { Vol. 1, no. 1, 1998, 57-73. }\end{array}$ & Janez Prasnikar & February 1997 \\
\hline $\begin{array}{l}\text { No. 25: Cultural Encounters and Claims to } \\
\text { Expertise in Postcommunist Capitalism }\end{array}$ & Michael D. Kennedy & February 1997 \\
\hline $\begin{array}{l}\text { No. 24: ZVU a.s.: Investment Funds on the } \\
\text { Board of Directors of an Engineering Giant }\end{array}$ & Tory Wolff & August 1995 \\
\hline $\begin{array}{l}\text { No. 23: The Role of Investment Funds in the } \\
\text { Czech Republic (joint publication with Czech } \\
\text { Management Center) }\end{array}$ & Dusan Triska & June 1996 \\
\hline $\begin{array}{l}\text { No. 22: Czech Investment Fund Industry: } \\
\text { Development and Behaviour (joint publication } \\
\text { with Czech Management Center) }\end{array}$ & Richard Podpiera & May 1996 \\
\hline $\begin{array}{l}\text { No. 21: Restructuring of Czech Firms: An } \\
\text { Example of Gama, a.s. (joint publication with } \\
\text { Czech Management Center) }\end{array}$ & Antonin Bulin & June 1996 \\
\hline $\begin{array}{l}\text { No. 20: YSE Funds: A Story of Czech } \\
\text { Investment Funds (joint publication with } \\
\text { Czech Management Center) }\end{array}$ & Michal Otradovec & November 1995 \\
\hline $\begin{array}{l}\text { No. 19: První Investicni a.s., The First } \\
\text { Investment Corporation (joint publication } \\
\text { with Czech Management Center) }\end{array}$ & Jaroslav Jirasek & August 1995 \\
\hline $\begin{array}{l}\text { No. 18: PPF a.s., The First Private Investment } \\
\text { Fund (joint publication with Czech } \\
\text { Management Center) }\end{array}$ & Michal Otradovec & November 1995 \\
\hline $\begin{array}{l}\text { No. } 17 \text { Published in: Post-Soviet Geography } \\
\text { and Economics, "Russia’s Managers in } \\
\text { Transition: Pilferers or Paladins?" Vol. 37, } \\
\text { o.7 (September 1996), pp. 397-426. }\end{array}$ & Susan J. Linz and Gary Krueger & November 1996 \\
\hline No. 16: Banks in Transition-Investment & With commentary and edited by Anna & January 1997 \\
\hline
\end{tabular}

Working Papers are available at:

www.wdi.bus.umich.edu 


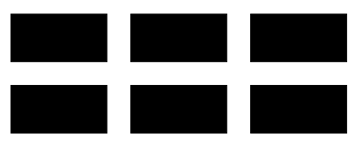

THE WILLIAM DAVIDSON INSTITUTE AT THE UNIVERSITY OF MICHIGAN BUSINESSSCHOOL

\begin{tabular}{|c|c|c|}
\hline $\begin{array}{l}\text { Opportunities in Central Europe and Russia } \\
\text { Edited Transcript from } 31 \text { May } 1996 \\
\text { Conference in New York City }\end{array}$ & Meyendorff & \\
\hline $\begin{array}{l}\text { No. 15: Marketing in Transitional Economies: } \\
\text { Edited Transcript \& Papers from } 1 \text { April } 1996 \\
\text { Conference in Ann Arbor, Michigan }\end{array}$ & Compiled by The Davidson Institute & December 1996 \\
\hline $\begin{array}{l}\text { No. 14: Pensions in the Former Soviet Bloc: } \\
\text { Problems and Solutions. Published by } \\
\text { Council on Foreign Relations. "The Coming } \\
\text { Global Pension Crisis" New York, } 1997\end{array}$ & Jan Svejnar & November 1996 \\
\hline $\begin{array}{l}\text { No. 13: Enterprise Restructuring and } \\
\text { Performance in the Transition. Forthcoming } \\
\text { in Financial Systems in Transition: The } \\
\text { Design of Financial Systems in Central } \\
\text { Europe eds. Anna Meyendorff and Anjan } \\
\text { Thakor. }\end{array}$ & $\begin{array}{l}\text { Lubomir Lizal, Miroslav Singer, and Jan } \\
\text { Svejnar }\end{array}$ & December 1996 \\
\hline $\begin{array}{l}\text { No. } 12 \text { Published in: Journal of International } \\
\text { Marketing, "Executive Insights: Marketing } \\
\text { Issues and Challenges in Transitional } \\
\text { Economies." Vol. 5, No. 4, 1997, pp. 95-114. } \\
\text { Also published in: Marketing Issues in } \\
\text { Transitional Economies ed. Rajeev Batra. }\end{array}$ & Rajeev Batra & April 1997 \\
\hline $\begin{array}{l}\text { No. 11: Worker Trust and System } \\
\text { Vulnerability in the Transition from Socialism } \\
\text { to Capitalism }\end{array}$ & Andrew Schotter & August 1996 \\
\hline $\begin{array}{l}\text { No. } 10 \text { Published in: Comparative Economic } \\
\text { Studies, "Russian Firms in Transition: } \\
\text { Champions, Challengers, and Chaff." Vol. 39, } \\
\text { No.2, Summer 1997, pp. 1-36. }\end{array}$ & Susan J. Linz & July 1996 \\
\hline $\begin{array}{l}\text { No. 9: Corporate Debt Crisis and Bankruptcy } \\
\text { Law During the Transition: The Case of China }\end{array}$ & David D. Li and Shan Li & December 1995 \\
\hline $\begin{array}{l}\text { No. } 8 \text { Published in: Journal of Comparative } \\
\text { Economics, "A Theory of Ambiguous } \\
\text { Property Rights in Transition Economies: The } \\
\text { Case of the Chinese Non-State Sector." Vol. } \\
\text { 23, No. 1, August 1996, pp. 1-19. }\end{array}$ & David D. Li & June 1996 \\
\hline $\begin{array}{l}\text { No. 7: The Foreign Economic Contract Law of } \\
\text { China: Cases and Analysis }\end{array}$ & Dong-lai Li & June 1993 \\
\hline $\begin{array}{l}\text { No. 3: Bank Privatization in Hungary and the } \\
\text { Magyar Kulkereskedelmi Bank Transaction }\end{array}$ & Roger Kormendi and Karen Schnatterly & May 1996 \\
\hline $\begin{array}{l}\text { Replacing Nos. 1-2 \& 4-6: Journal of } \\
\text { Comparative Economics Symposium on } \\
\text { "Bank Privatization in Central Europe and } \\
\text { Russia." Vol. 25, No. 1, August } 1997 .\end{array}$ & $\begin{array}{l}\text { No. } 1 \text { "Bank Privatization in Transitional } \\
\text { Economies" by Roger Kormendi and } \\
\text { Edward Snyder. No. } 2 \text { "Transactional } \\
\text { Structures of Bank Privatizations in } \\
\text { Central Europe and Russia" by Anna } \\
\text { Meyendorff and Edward A. Snyder. No. } 4 \\
\text { "Bank Privatization in Poland: The Case of } \\
\text { Bank Slaski" by Jeffery Abarbaness and } \\
\text { John Bonin. No. } 5 \text { "Bank Privatization in } \\
\text { Post-Communist Russia: The Case of } \\
\text { Zhilsotsbank" by Jeffery Abarbanell and } \\
\text { Anna Meyendorff and No. } 6 \text { "'The Czech }\end{array}$ & August 1997 \\
\hline
\end{tabular}

Working Papers are available at: www.wdi.bus.umich.edu 


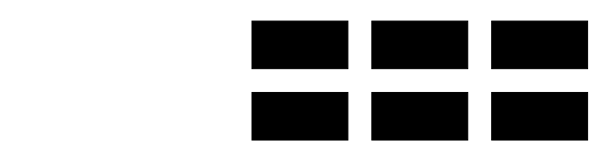

THE WILLIAM DAVIDSON INSTITUTE AT THE UNIVERSITY OF MICHIGAN BUSINESSSCHOOL

Republic's Commercial Bank: Komercni Banka" by Edward A. Snyder and Roger

C. Kormendi.

Working Papers are available at: www.wdi.bus.umich.edu 